\title{
faUplift and denudation history of the Akaishi Range, a thrust block formed by arc-arc collision in central Japan: Insights from low-temperature thermochronometry and thermo-kinematic modeling
}

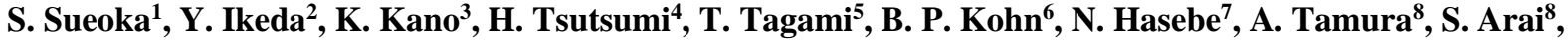 \\ and K. Shibata ${ }^{1}$
}

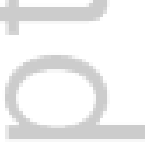

${ }^{1}$ Neotectonics Research Group, Japan Atomic Energy Agency, Toki, Gifu 509-5102, Japan

2 Department of Earth and Planetary Science, University of Tokyo, Hongo, Tokyo 113-0033, Japan

${ }^{3}$ Center for Integrated Research and Education of Natural Hazards, Shizuoka University, Ohya, Shizuoka $422-$ 8059, Japan

${ }^{4}$ Department of Geophysics, Division of Earth and Planetary Sciences, Graduate School of Science, Kyoto University, Kyoto 606-8502, Japan

${ }^{5}$ Department of Geology and Mineralogy, Division of Earth and Planetary Sciences, Graduate School of Science, Kyoto University, Kyoto 606-8502, Japan

${ }^{6}$ School of Earth Sciences, The University of Melbourne, Melbourne, Victoria 3010, Australia

${ }^{7}$ Institute of Nature and Environmental Technology, Kanazawa University, Kanazawa 920-1192, Japan

${ }^{8}$ Department of Earth Sciences, College of Science and Engineering, Kanazawa University, Kanazawa 9201192, Japan

Correspondingauthor:Shigeru Sueoka (sueoka.shigeru@jaea.go.jp)

Key Points:

- Thermochronometry revealed that thrusting uplifts the northern Akaishi Range.

- Geometry and slip rate of the thrust are estimated by thermo-kinematic modeling.

- Different uplift processes were suggested in the northern and southern Akaishi Range.

This is the author manuscript accepted for publication and has undergone full peer review but has not been through the copyediting, typesetting, pagination and proofreading process, which may lead to differences between this version and the Version of Record. Please cite this article as doi: $10.1002 / 2017 J B 014320$

This article is protected by copyright. All rights reserved. 


\begin{abstract}
Fission-track (FT), (U-Th)/He (He), and U-Pb data were used to identify the denudation history of the Akaishi Range, central Japan. The northern Akaishi Range is bounded on the east by the Itoigawa-Shizuoka Tectonic Line Fault Zone (ISTL-FZ). The thermochronometric ages progressively decreases with the decreasing distance to the ISTL-FZ. Thermo-kinematic calculations suggest that the age pattern observed can be explained by a $5-7.5 \mathrm{~mm} / \mathrm{yr}$ reverse slip on the ISTL-FZ that dips $34-45^{\circ}$ west and soles onto detachment at a20-22.5 km depth. By assuming the same geometry and slip rate of the fault, thebedrock uplift rates and denudation rates are estimated at $\sim 4 \mathrm{~mm} / \mathrm{yr}$. Thus, the uplift and denudation style of the northern Akaishi Range is well explained asa simple tilted thrust block that has been exhumed along the listric ISTL-FZ. On the other hand, considering both the difference in apatite FT age and the active fault distribution, the southern Akaishi Range might be different in uplift origin and timing, although the difference in apatite FT ages between them may be attributable to the chlorine content variation in apatite. The inferred total denudation is larger than several kilometers and likely exceeds $10 \mathrm{~km}$ since the beginning of the northern Akaishi Range uplift, suggesting that the low-relief surfaces on the ridges and the relatively constant elevations of the summits reflect post-uplift denudation rather than pre-existing low-relief landforms.
\end{abstract}

\title{
1 Introduction
}

Arc-arc collision is considered to be a primary process of continental growth [e.g., Taira et al., 1998; Yamamoto et al., 2009]. Central Japan is characterized asa collision zone between three island arcs (Figure 1):Northeast Japan and Southwest Japan arcs converge at the Fossa Magna region [e.g., Kimura, 1996; Miyazaki and Heki, 2001; Townend and Zoback, 2006], whereas the Izu-Bonin arc has perpendicularly collided with the Honshu Island from the south since the Middle Miocene [e.g., Matsuda, 1978; Amano, 1991; Kano, 2002; Hirata et al., 2010]. The Itoigawa-Shizuoka Tectonic Line (ISTL) borders the western margin of the Fossa Magna region. To the west of the ISTL, there are 3000-m-high mountain ranges known as the Japan Alps, which were formed in the last few million years [e.g., Moriyama, 1990a, 1990b; Yonekura et al., 2001, p.308].The Japan Alps consists of three major ranges, i.e., the Hida Range,the Kiso Range, and the Akaishi Range (Figure 1), which are thought to be different from one anotherin relation to the origin and onset age of the uplift [e.g., Kaizuka and Chinzei, 1986; Moriyama, 1990a, 1990b; Ikeda, 1996].

The purpose of this study istoelucidate the uplift and denudation history of the Akaishi Range and thereby to place constraints on its uplift mechanism. The Japanese Islands are young and form a small orogen, and therefore, the total amount of denudation related to the ongoing orogenesis is relatively low. Consequently, thermochronometric approaches,which are well knownto be powerful tools for reconstructing the denudation histories of orogens [e.g., Reiners and Brandon, 2006], are more difficult to apply for revealing the recent denudation history of the Japanese mountains. However, due to the recently developed low-temperature thermochronologic techniques, such as (U-Th)/He thermochronometry [e.g., Farley, 2002; Reiners, 2005] and thermal inverse calculations based on thermochronometric data [e.g., Ketcham, 2005], the uplift and denudation history of the Kiso Range over the last few million years has been revealed successfully [Sueoka et al., 2012]. The Akaishi Range is bordered on the east by the ISTL and is a component of the South Fossa Magna region, which is a collision zone between the Honshu Island and the IzuBonin arc (Figure 1b).Crustal blocks of the Izu-Bonin arc have sequentially collided with the Honshu Island since the Middle Miocene, such as the Kushigatayama Block at 15-13 Ma, the Misaka Block at 13-8 Ma, the Tanzawa Block at 8-5 Ma, and the Izu Block since $\sim 1 \mathrm{Ma}$ 
[e.g., Amano, 1991; Hirata et al., 2010]. Hence, to reveal the origin of the uplift of the Akaishi Range,effects by multiplefactors, such as faulting of the ISTL [e.g., Ikeda, 1996; Ikeda et al., 2009] and collision of crustal block(s)(or buoyant subduction, in a strict sense) of the Izu-Bonin arc [e.g.,Matsuda, 1978; Kaizuka and Chinzei, 1986; Kano, 2002], should be taken into account.Thus, revealing the uplift and denudation history of the Akaishi Rangewill lead to a clearer understandingof the process and mechanism of the orogenyassociated with an arc-arc collision, especially in its earliest stage.Here, we particularly focused on the northern part of the Akaishi Range (northern Akaishi Range) because the relationship between the mountain development and the adjacent active faultings is easier to examine. The reason is the clearerexposed active fault traces compared to those in the southern part of the Akaishi Range (southern Akaishi Range). In addition, granitoids suitable for thermochronometric studies are exposed in the northern Akaishi Range.We present here new low-temperature thermochronological data, including fission-track (FT) and (U-Th)/He ages (He ages), to reveal the denudation history of the northern Akaishi Range.In addition, thermo-kinematic modeling was performed to evaluate the roles of the adjacent fault zones in the northern Akaishi Range uplift. We also compare the northern and southern Akaishi Ranges on the basis of previous thermochronometric data and discuss the difference in the origin and timing of the uplift.

\section{Geomorphic and geologic settings}

The Akaishi Range is located to the west of the Fossa Magna region, the boundary zone between Northeast and Southwest Japan arcs(Figure 1b). The Akaishi Range, with its maximum elevation of 3,193 $\mathrm{m}$ above sea level, is one of the most extensive and highest mountain ranges in Japan. The Akaishi Range in a broad sense consists of three major mountain ranges, namely from west to east: the Ina Mountains, the Akaishi Range in a more restricted sense, and the Koma Mountains [Southern Alps World Natural Heritage Registration Promotion Meeting, 2010] (Figure 2).In this paper, "Akaishi Range" is generally used in the broad sense unless otherwise specified.The boundaries of the three mountain ranges are marked by the Median Tectonic Line (MTL) and the ISTL. The basement rocks of the Akaishi Range consist mainly of Jurassic to Paleogene accretionary complexes and Middle Miocene granitoids (Figure 3a).In the Akaishi Range in therestricted sense, accretionary complexes (the Sanbagawa Belt, the Chichibu Belt, and the Shimanto Belt) and Middle Miocene Kaikoma granite are distributedfrom west to east (Figure3a). The Sanbagawa Belt mainly consists of the Cretaceous metamorphic rocks, whereas the Chichibu and Shimanto Belts are composed mainly of sedimentary rocks formed from the Permian to Jurassic and the Cretaceous to Paleogene periods, respectively. The Todai Formation, which corresponds to lower Cretaceous neritic sediments, is also embedded in the Chichibu Belt.The Ina Mountains to the west consist of the Cretaceous granitic and metamorphic rocks of the Ryoke Belt, whereas the Koma Mountains to the east mainly consist of Neogene submarine volcaniclastic rocks, such as the Koma Group, and Middle Miocene Tsuburai granite. TheNeogene pyroclastic rocks distributed in the South Fossa Magna region, such as the Koma Group, were formed under multiple collisions of the Izu-Bonin arc [e.g., Yamamoto and Shimazu, 1998].

\subsection{Itoigawa-Shizuoka Tectonic Line Fault Zone}

The ISTL Fault Zone (ISTL-FZ) is composed of active main strands and their splay and branch faults. The ISTL-FZ is largely divided into an east-dipping northern segment marking the eastern margin of the Hida Range with a N-S elongated Matsumoto Basin in between, a west-dipping southern segment marking the eastern margin of the Akaishi Range, 
and a left-lateral central segment connecting the northern and southern segments (Figure 1b). The ISTL forms the geological boundary between the Southwest Japan and the Northeast Japan arcs. In Southwest Japan, the pre-Neogene basement rocks mainly composed of accretionary complexes, their metamorphic derivatives and intrusive rocks are predominant, while in Northeast Japan, the Neogene and Quaternary sedimentary and volcanic rocks are widely distributed within the subordinate occurrences of the pre-Neogene basement rocks. The northern segment of the ISTL was originally initiatedin the Middle Miocene related to the Japan Seaopening event [e.g., Yanai et al., 2010], whereas the southern segment of the ISTL was formed in association with an initialcollision of the Izu-Bonin arc against the Honshu Island [e.g., Kano, 2002]. Some parts of the ISTL have been reactivated under E-W compression in the last few million years, forming the presently active ISTL-FZ.

The southern part of the ISTL-FZ consists of the reactivated and subparallel strands of the ISTL, such as the Ho-osan and Hakushu faults on the west, and the Shimotsuburai and Ichinosefaults on the east (Figures1-3) [e.g., The Research Group for Active Faults of Japan, 1991]. The Shimotsuburai and Ichinose faults are the frontal faults of the Ho-osan and Hakushu faults.In this paper, andfor convenience, we name the former "the frontal thrust" and the latter "the boundary thrust". The frontal thrust is a border of the Koma Mountains and the Kofu Basin (Figures 2 and 3); the Kofu Basin is an inland basin filled with the Quaternary sediments. The southern part of the ISTL-FZis composed of west-dipping reverse faults [e.g., The Research Group for Active Faults of Japan, 1991].The dip of the frontal thrust is generally as low as $\sim 15^{\circ}$ near the surface [e.g., Kumamoto and Ikeda, 1993; Ikeda et al., 2009], whereas that of the boundary thrust is steeper [e.g., Ikeda et al., 2009]. The frontal and boundary thrusts are considered to sole into a single thrust fault at depth [e.g., Ikeda et al., 2009]. Considerably high dip slip rates of 3-11 mm/yr during the late Quaternary were estimated for the frontal thrust on the basis of the deformation of fluvial terraces [Hirakawa et al., 1989; Ikeda et al., 2009] as well as the subsurface structure obtained by seismic reflection [Ikeda et al., 2009] and gravity surveys [Kumamoto and Ikeda, 1993; Ikeda et al., 2009]. On the other hand, dip slip rates along the boundary thrust are smaller.Vertical slip rates of the Hakushu fault were estimated at $0.1-0.9 \mathrm{~mm} / \mathrm{yr}$ based on geomorphological investigations [Sawa, 1985; Tajikara, 2002; Miura et al., 2004], whereas the activity of the Ho-osan fault over the late Quaternary is still unclear and debatable [e.g., Tajikara, 2002]. The ISTL to the south of the Kofu Basin and the MTL in and around the Akaishi Rangehas generallybeen inactive or with low activity (right-lateral slip rate: $<0.1 \mathrm{~mm} / \mathrm{yr}$ ) during the late Quaternary [e.g., The Research Group for Active Faults of Japan, 1991; Nakata and Imaizumi, 2002].

\subsection{Uplift and denudation history of the Akaishi Range}

Based onstratigraphical and paleontological evidence, the onset of the Akaishi Range uplifthas beenestimated to beLate Pliocene [e.g., Kano et al., 1985; Kano, 2002].The upper Pliocene Akebono Conglomerate in the upper reaches of the Fuji River (Figure 8a) contains gravels of Shimanto sedimentary rocks, which provide the earliest signature of uplift/denudationof the Akaishi Range[Kano, 2002].The lowest part of the Akebono Conglomerate contains planktonic foraminiferans,approximately indicating the boundary of Zones N.19 and N.21 of Blow[1969][Kano et al., 1985; Akimoto, 1991], suggesting that the denudation over the Akaishi Rangehad started by 3.3 Ma [Kano, 2002].In the lower reaches of the Fuji River district, sedimentary clasts from the Akaishi Rangearefound in the lower-tomiddle Pleistocene Ihara Group [Shiba, 1990], but not in the upper Pliocene Hamaishidake Formation [Matsuda, 1984; Kano, 2002].In the Ina Basin to the west and Kakegawa district to the south, the lower Pleistocene Ina Group[Moriyama and Mitsuno, 1989; Moriyama, 
1990a; Matsushima, 1995; Suganuma et al., 2003] and the lower-to-middle Pleistocene Ogasa Group [Ishida et al., 1980; Muto, 1985], respectively (Figure 8a), are the oldeststratacontainingsedimentary clasts from the Akaishi Range.These observations suggest that the uplift of the Akaishi Range started in the northeastern part and extended to the west and southover time [Kano, 2002].

The amount and rate of the bedrock upliftsince the initiation of the uplift of the Akaishi Rangecannot be accurately estimated mainly due to the lack of datafor the long-term denudation history.Based on the elevation of erosional low-relief surfaces, the amount of the bedrock uplift was estimated at 1000-1500 m [Research Group for Quaternary Tectonic Map, 1968] and >2500 mbased on extrapolation from tilted uplift of the lower Pleistocene Ryuto Surface (depositional surface of the Ina Group), which islocatedalong the eastern margin of the Ina Basin [Moriyama and Mitsuno, 1989; Moriyama, 1990a]. These estimates assume that the low-relief surfaces or summit plain of the peaks basically represent the remnant of the peneplain surfaceprior to the uplift of the Akaishi Range and assume thatthe denudation was negligible.However, Sugai $[1990,1992]$ investigated the geometry and surface geology of the low-relief surfaces in the Akaishi Range, suggesting that majority of the surfaces distributed more than 1500-2000 m above sea level are periglacial smooth slopes. Namely, these surfaces wereformed at a high altitude due to erosion by periglacial processes.

In addition, Fujiwara et al.[1999]calculated denudation rates of the Akaishi Range at up to $3-5 \mathrm{~mm} / \mathrm{yr}$ by using the empirical relationship between the denudation rate and the altitude dispersion. Similarly, Ohmori [1987] computed bedrock uplift rates at up to 5-7 $\mathrm{mm} / \mathrm{yr}$ based on the correlation between the mean altitude and the bedrock uplift rate.In addition, short-term erosion rates estimated from sedimentation loads of the catchments [e.g., Yoshikawa, 1974; Ohmori, 1978; Tanaka, 1982; Fujiwara et al., 1999] and cosmogenic nuclide data [Korup et al., 2014] also indicate high denudation rates of up to a few or several $\mathrm{mm} / \mathrm{yr}$. These resultssuggestthat denudation significantly affected the landforms of the Akaishi Rangeand therefore the previous estimates of bedrock uplift were underestimated.

\subsection{Previous thermochronometric data}

Apatite and zircon FT(AFT and ZFT)ages from the Akaishi Range have beenpreviously reported [Tagami et al., 1988a;Ito et al., 1989;Tagami and Shibata, 1993;Yamagiwa et al., 1997; Yamagiwa, 1998MS] (Figures 2-3).Tagami et al.[1988a]andTagami and Shibata[1993]reportedZFT (57.0-50.1 Ma) and AFT (59-9.0 Ma) ages in the Ina Mountains, detecting younger AFT ages within a few kilometers from the MTL.Ito et al.[1989]reported ZFT ages of 10.9-7.8 Ma for the Kaikoma Granite and 15.314.5 Ma for the Tsuburai Granite, proposing differential thermo-tectonic histories of granitic bodies in the South Fossa Magna region.Yamagiwa et al.[1997] and Yamagiwa[1998MS]reported ZFT (101.9-9.1 Ma) and AFT (3.5-0 Ma)ages from sedimentary rocks of the Shimanto Belt in the Akaishi Range. The younger ZFT ages along the ISTLand AFT ages were interpreted as reflecting uplift and subsequent denudation episodes, which were caused by the collisions of the Kushigatayama block in the Middle Miocene and Izu blocks at $\sim 1 \mathrm{Ma}$, respectively [Yamagiwa, 1998MS].These previous data indicate that the closure temperature of the ZFT system is too high to reconstruct the denudation history of the Akaishi Range in the last few million years whilst that of the AFT system is too low. Note that a systematic thermochronometric study across the Akaishi Range was not conducted. Therefore, we performed additional thermochronometric investigations by using the zircon ( $\mathrm{U}-\mathrm{Th}) / \mathrm{He}(\mathrm{ZHe})$ method as well as ZFT and AFT methods across the northern Akaishi Range. 


\section{Thermochronometric analyses}

Samples were collectedalong east-west profiles, perpendicular to the general direction of the Akaishi Range andthe major geologic units/structures (Figures2 and 3a,b), to detect variationsinthe thermochronometric age pattern, i.e., the denudation history across the northern Akaishi Range. Samples were obtained from the Tsuburai granite, Kaikoma granite, sandstones of the Shimanto Belt, sandstone layers of the Chichibu Belt (including sandstones of the Todai Formation), and alternating psammitic and peliticschistsof the Sanbagawa Belt (Tables 1-2, Figure 3a). The Tsuburai granite and Kaikoma granite were intensively sampled because the denudation history in the eastern part of the northern Akaishi Range close to the ISTL-FZ is more important, and because the quality and quantity of apatite and zircon generally yield the bestfromthe granitic rocks.

We conducted $\mathrm{He}, \mathrm{FT}$, and U-Pb analyses. FT analyses were performed on apatites and zircons, whilst $\mathrm{He}$ and $\mathrm{U}-\mathrm{Pb}$ dating were carried out only on zircons.Apatite He analyses were not performed because apatites are often roundedand may show poor morphologyin sedimentary and metamorphic rocks; euhedral, unbroken, and properlywide (> 60 $\mu \mathrm{m})$ apatites are favorable for He dating [e.g., Farley, 2002].Hence, the apatite He analysis would only besuitable in the eastern part of the study area, and then it would be difficult to evaluateany age variations from west to east.In addition, considering the previously reported very young AFT ages of 3.5-0 Ma [Yamagiwa et al., 1997; Yamagiwa, 1998MS], apatite He ages are expected to be uniformly young all over the study area.Mineral separation was conducted at Kyoto University by means of magnets and heavy liquids[Tagami et al., 1988b]. The detailed procedures of $\mathrm{He}, \mathrm{FT}$, and $\mathrm{U}-\mathrm{Pb}$ analyses are provided in Text $\mathrm{S} 1$ and $\mathrm{S} 2$, respectively.

\section{Analytical results and interpretation}

Tables1 and 2summarize theobtained FT and $\mathrm{ZHe}$ data, respectively.ZirconU-Pb ages are presented in Figure 4 with theconcordia plots, and the detailed data are presented in Table S1.Figure 3cis a plot of azimuth $v$ s thermochronometric ages obtained in this study and previous studies [Tagami et al., 1988a;Ito et al., 1989;Tagami and Shibata, 1993;Yamagiwa et al., 1997; Yamagiwa, 1998MS].Histograms of ZFT length are also shown in Figure 5.

\subsection{Z $\mathrm{He}$ analysis results}

ZHe grain ages range 21.5-3.0 Ma (Table 2). The grain ages are generally reproducible for each sample and the weighted mean ages are systematically younger toward the east (Table 2; Figure 3c); only \#10 shows a wide dispersion among the grain ages;therefore, the weighted mean age was not adopted.Ojr-3, the closest sample to the boundary thrust (Figure 3), produces the youngest weighted mean age of 3.4 $\pm 1.1 \mathrm{Ma}$, which is consistent with the onset of the uplift of the Akaishi Range, $3.3 \mathrm{Ma}$ [Kano, 2002].

\subsection{Zircon $\mathrm{U}-\mathrm{Pb}$ dating results}

Zircon U-Pb ages range 13.8-12.3 Ma for the Kaikoma granite and $15.9 \pm 0.6 \mathrm{Ma}$ $( \pm 1 \sigma)$ for the Tsuburai granite (Table S1, Figures 3c and 4).All of the grain ages of the Kaikoma granite were regarded as concordant and only one grain of the Tsuburai granite was regarded as discordant; grain ages of each sample produce a single population (Table S1, Figure 4).The homogeneity of the grain ages implies that they are not inherited ages although the measurements were basically performed on the core parts of the zircons.In addition, all of the weighted mean ages of the Kaikoma granite samples overlap at the $\pm 2 \sigma l e v e l$.Therefore, considering that the closure temperature of the zircon $\mathrm{U}-\mathrm{Pb}$ system $\left(>900^{\circ} \mathrm{C}\right.$ [Cherniak and 
Watson, 2000]) is higher than the solidus of granitic magma, these ages are interpreted to reflect the early stage of the zircon crystallization, providing the approximate crystallization ages of the granitic bodies. These ages overlap or are older than the previously reported ZFT and K-Ar ages [e.g., Ito et al., 1989; Sato et al., 1989] and are considered to bereasonableconsidering the difference in their closure temperatures. The zircon $\mathrm{U}-\mathrm{Pb}$ age of the Tsuburai Granite is also consistent with some geologic observations. Namely, the U-Pb age equals or is slightly younger than the depositional age of the Kushigatayama Subgroup of the Koma Group belonging to Zones N.8 and N.9 of Blow [1969] [Akimoto et al., 1990], which was intruded by the Tsuburai granite. Moreover, the $\mathrm{U}-\mathrm{Pb}$ age equals or is slightly older than the collision age of the Kushigatayama Block at 15-13 Ma [e.g., Amano, 1991; Hirata et al., 2010].

\subsection{ZFT dating results}

ZFT pooled ages range 10.0-5.6 Ma for the Kaikoma granite, and $14.4 \pm 0.8(2 \sigma) \mathrm{Ma}$ for the Tsuburai granite (Table 1). The ages forthe Kaikoma granite and Tsuburai granite are consistent with the ZFT ages previously reported byIto et al. [1989](Figure 3c).ZFT ages of the Tsuburai granite overlap the zircon $\mathrm{U}-\mathrm{Pb}$ age within the range of the errors.In addition, the FT lengths are not shorter than the initial length $(\sim 11 \mu \mathrm{m}$; e.g., Hasebe et al., 1994; Yamada et al., 1995) and produce a narrow unimodal population (Figure 5), indicating a rapid cooling history through the ZFT partial annealing zone (PAZ).Therefore, the Tsuburai granite is thought to have cooled to temperature below the ZFT PAZ immediately after the intrusion.In contrast, ZFT ages of the Kaikoma granite are significantly younger than the zircon $\mathrm{U}-\mathrm{Pb}$ ages at the $2 \sigma$ level and are slightly younger toward the east (Figure $3 \mathrm{c}$ ). The FT lengths are also slightly shorter to the east, indicating a negatively skewed unimodal pattern at the western localities (\#5, Ojr1, Ojr2, Hou2, and Ykt) and bimodal pattern at the easternmost localities (Ojr3 and Ohm3) (Figure 5).

ZFT pooled ages of the accretionary complexes ranging 109.4-45.5 Maare older than those of the Tsuburai granite and Kaikoma granite.Interpretations of the ZFT ages of the accretionary complexes are not as simple as those of the granitoids because the ages are usually derived from multi-populations of grain ages and some of the populations are older than the depositional ages, indicating inherited ages that reflect accretionary processes and/or pre-accretionary processes [e.g., Hasebe et al., 1993, 1997; Wallis et al., 2004].Referring to such old events is beyond the scope of this study and the detailed discussions and interpretations about the ZFT ages as well as the corresponding zircon $\mathrm{U}-\mathrm{Pb}$ agesthat are considered to reflect geological events in the provenance regions [e.g, Nakama et al., 2010; Isozaki et al., 2010] will be provided in another paper.In this study, the observation about the ZFT ages being older than theircoexisting ZHe and AFT ages is used for the following discussion.

Generally, measured FT ages are verifiedby $\chi^{2}$-test fortheir involvement of nonPoissonian factors, such as misidentification of FTs, zoning of uranium content perpendicular to the observed surfaces, mixture of age populations, etc.[Galbraith, 1981; Green, 1981].However, we used spot analyses by LA-ICP-MS for measuring the uranium content, inevitably leading to mismatches between areas on which FTs are counted and uranium contents are measured.These mismatches can be latent and essentially non-Poissonian factors so that we have not applied the $\chi^{2}$-test to the FT ages. The data accuracy is assured by age standards obtained by the same procedures and systems (Table 3 ). The recentlysuggested alternative $Q_{\text {stat }}$ [Galbraith, 2010; Hasebe et al., 2013] is also shown for reference; generally, $\chi^{2}$-probability of $>5 \%$ were obtained for age standards and for the Tsuburai granite, which 
cooled down rapidly, but not for other samples that cooled down relatively slowly (Tables 1 and 3).

\subsection{AFT analysis results}

AFT pooled ages range 8.2-3.1 Ma for accretionary complexes and the Kaikoma granite and 18.5-14.3 Ma for the Tsuburai granite (Table 1; Figure 3c).AFT ages west of the boundary thrust are generally younger than ages from higher-temperature thermochronometers obtained from the same samples.In contrast, AFT ages of the Tsuburai granite overlap within the range of $2 \sigma$ of their corresponding ZFT and zircon $\mathrm{U}-\mathrm{Pb}$ ages.However, we reject the AFT ages fromthe Kaikoma granite and the Tsuburai granite because densedislocation features were observed forthese samples, especially for samples close to the ISTL-FZ.Furthermore, since the measured apatites generally have very low FT densities (Table 1), only a few misidentified track-like dislocations could lead to age overestimation. Therefore, we regard the AFT ages of the granitoids as the older limits of the true values.AFT age of \#9 obtained from the sandstones of the Todai Formation was adopted;however, it should be noted that the apatites have very high $\mathrm{Cl}$ content of $>1 \mathrm{wt} \%$ (Table 1), indicating a higher closure temperature than thegenerallyadoptedrange of 90 $120^{\circ} \mathrm{C}$.

Although we also tried to measure FT lengths on apatites, reliable data were not obtained due to the dense dislocations and low FT densities. The problem of low FT densities was moderated by adopting ${ }^{252} \mathrm{Cf}$-irradiations [Donelick and Miller, 1991] at the University of Melbourne.However, separating FTs from dislocations was difficult, especially for annealed shorter FTs, which are more important for reconstructing the cooling histories.Larger diameters of the etch pits related to the higher $\mathrm{Cl} w \mathrm{w} \%$ [e.g., Donelick et al., 2005] also hindered the observations of FTs. The dislocation density was generally higher to the east and is possibly related to proximity to deformation along the ISTL-FZ.

\section{Thermo-kinematic modeling}

ZFT and ZHe ages generally get young toward the east, with the youngest age attained at the boundary thrust(Figure. 3c). The youngest ZHe mean age (sample OJR-3) overlaps with $\sim 3.3 \mathrm{Ma}$ within the error range, consistent with the previously estimated age of the onset of uplift (Table 2).Furthermore, AFT ages are younger on the western side of the boundary thrust than the eastern side although the ages are less accurate, as discussed above.These observations indicatethe uplift of the northern Akaishi Range since the Late Pliocene is mainly attributable to theboundary thrust rather than the frontal thrust.

To verify this hypothesis and constrain detailed fault parameters of the ISTL-FZ, forward 3-D thermo-kinematic modeling by using Pecube version 3 [Braun, 2003; Braun et al., 2012] was performed.Pecube solves the heat production-diffusion-advection equation by the finite element method, capable of predicting thermochronometric ages obtained at the surface that resulted from topographic relief changes and fault displacements [Braun et al., 2012].In this study, parameter studies on the slip rate and subsurface geometry of the boundary thrust were attempted (Figure 6) under a common tectonic scenario consisting of the following steps: 1) no relief change and fault displacement, namely, no bedrock uplift and denudation, occurring from $15 \mathrm{Ma}$ to $3.3 \mathrm{Ma}$; 2) faulting of the boundary thrust and relief growth of the northern Akaishi Rangestarting at 3.3 Ma; and 3) the present landform is completed at $0 \mathrm{Ma}$ (Figure $6 \mathrm{c}$ ). The constant slip rate since $3.3 \mathrm{Ma}$ is justified by the invariance of the direction and the rate of the Philippine Sea plate motion since the Late Pliocene [e.g., Kimura et al., 2005; Takahashi, 2006]. 
The summary of the model parameters is shown in Table 4.A simple flat-ramp structure was assumed (Figure 6a) and the fault parameters were changed in terms of the dip of the ramp, $\theta$, from $\tan \theta=1 / 4\left(\approx 14^{\circ}\right)$ to $1 / 1\left(=45^{\circ}\right)$; depth of the detachment, $Z_{\mathrm{d}}$, from 10 to $25 \mathrm{~km}$; and dip-slip rate, $V$, from 5 to $25 \mathrm{~mm} / \mathrm{yr}$ (Tables 5 and 6, Figure 7).A pure reverse fault is assumed, and the strike-slip component is regarded as negligible. The elastic thickness was set at $12.5 \mathrm{~km}$ according to Kudo et al. [2001]. Although spatial resolution of the elastic thickness shown in Kudo et al. [2001] is low, parameter studies indicate that the elastic thickness cause less significant difference on the modeling results (Figure $\mathrm{S} 1$ ) compared to $Z_{\mathrm{d}}, \theta$, and $V$ (Figure 7). The model depth and temperature at the model base were adopted at $30 \mathrm{~km}$ and $750^{\circ} \mathrm{C}$, respectively, because Iio and Kobayashi [2002] calculated the temperature at $30 \mathrm{~km}$ below the surface in the Nojima area, a non-volcanic region of Southwest Japan arc with the Akaishi Range, at around $700-800^{\circ} \mathrm{C}$. The surface temperature was assumed to be $15^{\circ} \mathrm{C}$ at sea level,decreasingwith elevation at a rate of $6^{\circ} \mathrm{C} / \mathrm{km}$. The topographic model was constructed using 3 arc-second elevation data of Shuttle Radar Topography Mission (SRTM3).Thermal effects on the ages by the volcanoes to the east of the study area, i.e., Mts. Yatsugatake and Fuji (Figure 2), are regarded to be negligible because the present geothermal gradient in the study area range a general value of ca 20 $40^{\circ} \mathrm{C} / \mathrm{km}$ [Tanaka et al., 2004]. Moreover, geothermal gradients generally attainthe background level at a distance greater than $\sim 10-20 \mathrm{~km}$ from the major Japanese volcanoes [Umeda et al., 1999].In fact, the decrease of the ages toward the north, at a distance from Mts. Yatsugatake, was not obviously identified (Tables 1 and 2). Frictional heating along the fault plane is not incorporated because duration of frictional heating is so short that thermochronometric ages can get younger only within a few millimeters or centimeters from the fault plane [e.g., d'Alessio et al., 2003; Murakami and Tagami, 2004].See also Braun [2003] and Braun et al.[2012] for the further details of the concept, model settings, and functions of Pecube.

\section{Modeling results and interpretation}

Summaries of the calculated results are shown in Tables 5 and 6 and Figure 7.The aerial extent at which younger ages are observed depends strongly on the subsurface fault geometry, i.e., $\theta$, and $Z_{\mathrm{d}}$ (Table 5; Figure 7a).On the other hand, the youngest age of each thermochronometer is mainly determined by $V$ for a given fault geometry (Table 6; Figure 7b).Therefore, to determine fault parameters capable of reconstructing the observed thermochronometric age pattern shown in Figure 3c, two criteria were installed.Criteria I set the range at which younger ages are observed: a) AFT age $>10 \mathrm{Ma}$ at $138.0^{\circ} \mathrm{E}$, b) $\mathrm{ZHe}$ age $>5$ Ma at $138.1^{\circ} \mathrm{E}$, and c) AFT age $<10 \mathrm{Ma}$ at $138.1^{\circ} \mathrm{E}$ - these are applied to choosethe better combinations of $Z_{\mathrm{d}}$ and $\theta$ (Table 5; Figure 7a). Criteria II are set about values for the youngest ZFT and ZHe ages: a) the minimum ZFT age is $10-5 \mathrm{Ma}$ and b) the minimum ZHe age $<5 \mathrm{Ma}$ - these are applied to select better $V$ for fault geometries that passed criteria I (Table 6; Figure 7b).Note that the upper limit of the computed ages is about $15 \mathrm{Ma}$, so the ages of accretionary complexes and Ryoke granitoids are underestimated if the total exhumation since $15 \mathrm{Ma}$ is less than the closure temperature isotherm depth (Figure S2). For example, Criterion Ia is equivalent to AFT age older than $\sim 20-30 \mathrm{Ma}$ if the formation age of the rock is $\sim 60 \mathrm{Ma}$. On the other hand, difference in formation age of the rocks does not affect the minimum ages if the rocks are exhumed from the total annealing zone of the thermochronometric system.

Among the combinations of parameters tested, six combinations passed both criteria I and II (Tables 5-6; Figures 7c1-c6).In addition to the six combinations, two more combinations which have slip rates between values shown in Figures $c 7$ and c8 and Figures 
c9 and c10 respectively are thought to pass the criteria. Thus, eight combinations in total eventually passed the criteria. However, taking into account that both the Conrad depth [Katsumata, 2010] and the D90 depth [Asano et al., 2010] are estimated at around $20 \mathrm{~km}$ or slightly deeper around the study area, $Z_{\mathrm{d}}$ should be as deep as around 20-25 $\mathrm{km}$.Consequently, three combinations shown in Figures $7 \mathrm{c} 1, \mathrm{c} 2, \mathrm{c} 7-8$, i.e., $Z_{\mathrm{d}}=20-22.5 \mathrm{~km}$, $\tan \theta=1 / 1.5-1 / 1\left(\theta=34-45^{\circ}\right)$, and $V=5-7.5 \mathrm{~mm} / \mathrm{yr}$, best explain the data. These values are consistent with previous estimates, i.e., fault dip of $35^{\circ}-40^{\circ}$ obtained by seismic array observation [Panayotopoulos et al., 2010] and dip slip rate of 3-11 mm/yr along the frontal thrust [Hirakawa et al., 1989; Kumamoto and Ikeda, 1993; Ikeda et al., 2009] assuming a thrust-front migration [Ikeda, 1983] from the boundary thrust to the frontal thrust [Tajikara, 2002]. Based on simple trigonometric calculations and using the slip rates and fault dips, the bedrock uplift rates are estimated at $\sim 4 \mathrm{~mm} / \mathrm{yr}$ for the three best cases ( $V_{\mathrm{H}}$ in Table 6 ).

Because a steady-state condition can be easily attained if such a high bedrock uplift rate has continued since 3.3 Ma [e.g., Ohmori, 1978, 1985], recent denudation rates are also determined at $\sim 4 \mathrm{~mm} / \mathrm{yr}$, comparable to the bedrock uplift rates.

\section{Discussion}

\subsection{Origin of the northern Akaishi Range uplift}

Concerning the origin of the uplift of the Akaishi Range, a variety of factors should be taken into account, e.g., the reverse faulting of the ISTL-FZ[e.g., Moriyama, 1990b; Ikeda, 1996; Tajikara, 2002; Ikeda et al., 2009],the collision of the Izu-Bonin arc with the South Fossa Magna area [e.g., Matsuda, 1978; Kaizuka and Chinzei, 1986; Yamagiwa, 1998MS], the collision between Northeast and Southwest Japan arcs [Townend and Zoback, 2005], and the steady subduction of the Philippine Sea platewith steady accumulation of slip deficits [Hashimoto et al., 2008; Hashima et al., 2016], although these factors are not necessarily exclusive.Our thermochronometric and thermo-kinematic modeling results obtained for the northern Akaishi Rangesupport the scenario that the uplift is directly brought by faulting along the ISTL-FZ since $~ 3.3 \mathrm{Ma}$. The onset of the uplift, namely, the activation of ISTL-FZ, might be derived from the formation of the $\mathrm{E}-\mathrm{W}$ compression in the Japanese Island due to the motional change of the Philippine Sea plate from NNE to NW, and the subsequent westward migration of the Japan Trench since the Late Pliocene [Takahashi, 2006].The slip direction of active faults in central Japan can be explained by the present E-W constriction according to the stress inversion calculation of fault-slip data [Tsutsumi et al., 2012], although ISTL-FZ data were not included in their analyses.

On the other hand, the contribution of the Izu-Bonin arc collision is thought to be less significant. If the northern Akaishi Range was uplifted due to collision(s) of crustal block(s) of the Izu-Bonin arc, the onset of the uplift is expected to occur simultaneously with one of the collision events. In addition, although the Philippine Sea plate had moved to NNW prior to the Late Pliocene [e.g., Angelier and Huchon, 1987; Kimura et al., 2005; Takahashi, 2006], kinematic calculations suggested that the collision of the Izu-Bonin arc might not uplift the Akaishi Range when the Philippine Sea plate moved to NNW [Hashima et al., 2016]; the calculations were conducted on the Izu Block, but the general tendencies are expected to be applicable to the other blocks. Furthermore, in the Tanzawa Mountains to the east of the Akaishi Range, an acceleration in the exhumation rate in the past few million years was not detected by multi-system thermochronometry, in spite of the collision of the Izu Block since $~ 1 \mathrm{Ma}$ [Yamada and Tagami, 2008; Tani et al., 2010].This may suggest that the areas that are uplifted by collisions of the Izu-Bonin arc are limited and/or localized even around the colliding block. 
It is also notable that the uplift of the northern Akaishi Range is mainly driven by the boundary thrust rather than the frontal thrust, although the latter has been more active in the late Quaternary [e.g., Tajikara, 2002; Ikeda et al., 2009]. A possible scenario is that the northern Akaishi Rangehas been mainly uplifted by thrusting of the boundary thrust through the uplift history, and thatthe thrust-front migration [Ikeda, 1983] from the boundary thrust to the frontal thrustoccurred later, as proposed by Tajikara [2002] from investigations of the active faults and fluvial terraces. This scenariois supported by geomorphic observations. First, the difference in elevation is more obvious across the boundary thrust rather than the frontal thrust (Figure 3b), i.e., the total vertical displacement seems larger along the boundary thrust than along the frontal thrust. Furthermore, remnants of uplifted peneplains prevail on the eastern side of the boundary thrust but not on the western side (Figure 2) [Sugai, 1990], thus indicatingthat the total denudation since the onset of the uplift is smaller on the eastern side; otherwise, suchremnants of peneplain surfaces would have been eroded away.

The contribution ofthe faulting onthe MTL to the uplift of the northern Akaishi Range is thought to be negligible.Based on the thermo-kinematic modeling results, the observed ages, including the younger AFT ages on the western side of the MTL [Tagami et al., 1988a; Tagami and Shibata, 1993], can be explained only by the thrusting effect of the ISTLFZ.This result is consistent with the previous geomorphic and geologic observations, wherethe MTL in the area was inactive or of low activity in the late Quaternary [e.g., Moriyama and Mitsuno, 1989].Consequently, the uplift and denudation style of the northern Akaishi Range is explained by the simple tilted uplift model of Figure 6 of Sueoka et al. [2012]based on the following points: 1) the uplift is attributable only to one of the marginal faults; 2) the topographic cross-section is skewed to the opposite side of the fault (Figure 3b); and 3 ) the thermochronometric ages are younger, and thus, denudation rates increase toward the fault (Figure 3c).This uplift model can also explain the time-lag between the onset of the gravel supply from the Akaishi Range to basins to the east and west, i.e., 3.3 Ma in the watershed area of the Fuji River to the east [e.g., Kano et al., 1985; Kano, 2002] and Early Pleistocene in the watershed area of the Tenryu River [e.g.,Moriyama and Mitsuno, 1989; Matsushima, 1995; Suganuma et al., 2003].

7.2Difference in uplift/denudation history between the northern and southern Akaishi Range

The northern Akaishi Range is interpreted as a simple tilted thrust fault block uplifted since the Late Pliocene, but it is debatable if this interpretation is applicable to the southern Akaishi Range.Yamagiwa et al.[1997] and Yamagiwa[1998MS] reported younger AFT and older ZFT ages in the southern Akaishi Rangecompared with those in the northern Akaishi Range (Figure 8).In addition, the ISTL-FZ that is responsible for the uplift of the northern Akaishi Rangedoes not extend to the south of the Kofu Basin (Figure 8). The younger AFT ages in the southern Akaishi Range can be explained by the difference in the uplift and denudation history: 1) the onset of the uplift occurs later and the uplift and denudation rates are higherin the southern Akaishi Rangethan in the northern Akaishi Range;or 2) the onset of the uplift is coeval in whole of the Akaishi Range but the uplift and denudation rates are higher in the southern Akaishi Range.The former scenario is more plausible because itagrees with the observation that the supply of gravels from the Akaishi Range to the south in the Kakegawa areaonly commenced since $\sim 1 \mathrm{Ma}$,as reported by the Ogasa Group [Ishida et al., 1980; Muto, 1985], while in the latter case, ZFT ages are expected to be younger in the southern Akaishi Range.Moreover, deeper buried structures of the accretionary complexes, such as phyllite [e.g.,Kano, 2002] and higher illite crystallinity [Kanemoto and Otsuka, 2000; Kano et al., 2012], are exposed in the northern Akaishi Rangerather than in the southern 
Akaishi Range; itmay indicate a greater total denudation in the northern Akaishi

Rangeassuming a homogeneousgeothermal gradient.However, it is unknown if the difference in the total denudation is related to the recent different denudation episodes. The bimodal distribution of maximum elevations in the $\mathrm{N}-\mathrm{S}$ direction (Figure $8 \mathrm{~b}$ ) and the westward shifting of the main ridges in the southern Akaishi Range (Figure 8a) supports the differential uplift and denudation histories of the northern and southern Akaishi Range.However, Yamagiwa et al.[1997] and Yamagiwa[1998MS]did not reportapatite FT length and Cl wt\% data;therefore, it is difficult to verify the possibility that the younger AFT ages in the southern Akaishi Range were derived from lower $\mathrm{Cl}$ wt\%in apatite.Actually, in this study,relatively high $\mathrm{Cl}$ wt\% apatites were obtained from several samples inthe northern Akaishi Range (Table 1).

The faulting of the Fujikawa Kako Fault Zone,the Minobu fault to the east (Figure 8), and the collision of the Izu Block since $\sim 1$ Ma are possible candidates for the origin of the southern Akaishi Range uplift rather than the inactive strands of the ISTL, which bordersthe southern Akaishi Range.Based on displacements of the upper Pleistocene to Holocene strata,the vertical slip rate of the Fujikawa Kako Fault Zone was estimated at $5-8 \mathrm{~mm} / \mathrm{yr}$ [e.g., Yamazaki, 1992; Maruyama and Saito, 2007]. The Minobu fault isgenerally left-lateral and the slip rate of $>0.7 \mathrm{~mm} / \mathrm{yr}$ was computed from offsets of fluvial terrace scarps formed at $\sim 30 \mathrm{ka}$ [Mizumoto et al., 2016].Considering the strike, slip direction, and slip rate, the Fujikawa Kako Fault Zone is thought to be more plausibleto uplift the southern Akaishi Range than the Minobu fault.A kinematic simulation indicates that most of the Akaishi Range, including the southern Akaishi Range, can be uplifted by steady subduction of the Philippine Sea and Pacific plates in the present directions as well as by a slip-rate deficit around the Izu Peninsula, i.e., the effect of the Izu Block collision since 1 Ma [Hashimaet $a l ., 2016]$.For further discussion, additional thermochronometric investigations in the southern Akaishi Range are desirable, including ZHe analyses and studies in the Tenshu Mountains and Minobu Mountains, which arelocated between the southern Akaishi Range and the Fujikawa Kako Fault Zone, and the Minobu fault, respectively.

If the northern and the southern Akaishi Ranges are originally different mountain ranges, the boundary seems to be present around the southern end of the Kofu Basin or the Hayakawa River in the eastern side, and around the southern end of the Ina Basin or the Tohyama River (Figure 8a). The Kofu Basin and Ina Basin were formed primarily by faultings [e.g., Matsushima, 1995; Ikeda et al., 2009], similar to the uplift of the northern Akaishi Range. Thus, it is plausible that the southern ends of these basins are in accordance with those of the northern Akaishi Range. Considering a more detailed distribution of the active faults, the boundary in the eastern side can slightly shift southward to around the Hayakawa River, because the Akebono fault to the north of the Hayakawa River might have uplifted the western side by more than $\sim 5 \mathrm{~km}$ after the deposition of the Akebono Conglomerate [Kano et al., 1985]. On the other hand, the AFT ages of Yamagiwa [1998MS] suggest the boundary around the southern end of the Kofu Basin (Figure 8b). Although the two observations seem conflictive, it is also plausible that there is a transitional zone between the northern and the southern Akaishi Ranges. In such a zone, thermochronometric ages are expected to be overprinted by reflecting the later uplift of the southern Akaishi Range, even though the zone was originally uplifted as a part of the northern Akaishi Range. In the western side, the exposure width of the Sanbagawa and the Chichibu Belts drastically changes across the Tohyama River (Figure 8a). Although this observation may suggest a difference in the denudation history between the northern and southern sides of the Tohyama River, it is unclear if this structure was formed as a result of the differential uplift of the northern and the southern Akaishi Ranges. Difference in precipitation rate might be also 
related to the differential uplift of the northern and southern Akaishi Ranges. Precipitation rates range 1,500-2,000 mm/yr and 2,000-3,000 mm/yr in the northern and southern Akaishi Range, respectively

(http://www.data.jma.go.jp/obd/stats/data/mdrr/atlas/precipitation_13.pdf). Namely, higher and later uplift of the southern Akaishi Range might have brought the higher precipitation and denudation rates in the southern Akaishi Range [cf. Willett, 1999].

\subsection{Implications for formation of theeroded surfaces}

Based on the thermo-kinematic modeling results, the bedrock uplift rates of the northern Akaishi Range are estimated at $\sim 4 \mathrm{~mm} / \mathrm{yr}$, suggesting a total denudation from several to more than $10 \mathrm{~km}$ since $\sim 3.3 \mathrm{Ma}$, even after subtracting $\sim 3 \mathrm{~km}$ used for the relief growth from the total bedrock uplift over that time.Taking into account such high rates and amounts of denudation, the presence of low-relief surfaces on the ridges and relatively constant elevations of the summits could be attributed to post-uplift processes, such as periglacial erosion [Sugai, 1990, 1992], gravitational deformations or landslides [Matsuoka, 1985;Higaki, 1996;Mokudai and Chigira, 2004], and dynamic equilibrium between the bedrock uplift and the denudation [Ohmori, 1978, 1985, 1987] rather than pre-uplift processes such as peneplanation. This interpretation does not conflict with the idea that there were low-relief and low-elevation peneplains prior to the uplift of the northern Akaishi Range. For example, the Oi River in the southern Akaishi Rangeis characterized by incised meanders [e.g., Southern Alps World Natural Heritage Registration Promotion Meeting, 2010]. This implies that the region was originally low-relief, allowing the formation of meandering rivers, and later rapidly uplifted and incised.

7.4Denudation rates of the Japan Alps region and their implications

Besides the high denudation rate of $\sim 4 \mathrm{~mm} / \mathrm{yr}$ in the northern Akaishi Range obtained in this study, comparably high denudation rates have been inferred for the Japan Alps regionsince a few to $\sim 1 \mathrm{Ma}$.The Kiso Range has been denuded at the rate of 1.3-4.0 mm/yr since the initiation of the uplift at $\sim 0.8 \mathrm{Ma}$ according to the ZFT, AFT, and AHe data [Sueoka et al., 2012].In the Takidani region in the southern part of the Hida Range, the denudation rates range 5.1-5.9 mm/yr since $~ 1.9-1.5 \mathrm{Ma}$ [Bando et al., 2003], where Quaternary granitoids are exposed at the surface [Harayama, 1992] and their formation depths from Alin-hornblende geobarometryhave been estimated at 6.3-9.4 km [Bando et al., 2003].Comparable rapid denudation rates are expected in the Kurobe region in the northern Hida Range because substantial granitoids formed at 10-0.8 Ma are exposed [Ito et al., 2013].Considering the young AFT ages obtained by Yamagiwa [1998MS] (Figure 8b), the southern Akaishi Range is also expected to be denuded at a few $\mathrm{mm} / \mathrm{yr}$ or a higher rate.These high denudation rates have probably been sustained up to the present because comparably high rates were estimated over shorter time scales from sediment delivery rates of catchments [e.g., Yoshikawa, 1974; Ohmori, 1978; Fujiwara et al., 1999] and cosmogenic nuclide data [e.g., Matsushi et al., 2014; Korup et al., 2014].Such high denudation rates are observed only in limited regions of the world, such as, continent-continent collision zones, e.g., the Himalayas and New Zealand, and arc-continent collision zones, e.g., Taiwan, and Papua New Guinea [e.g., Montgomery and Brandon, 2002; Herman et al., 2013].These high denudation rates obtained in the Japan Alps region demonstrate that this region is one of the most tectonically active regions and of relatively high precipitation in the world, as pointed out byYoshikawa [1984]; the precipitation rates range 2,000-4,000 $\mathrm{mm} / \mathrm{yr}$ in the Japanese Alps according to the normal precipitation during 1981-2010 (http://www.data.jma.go.jp/obd/stats/data/mdrr/atlas/precipitation_13.pdf). In addition, this 
observation suggests that arc-arc collision can bring such a rapid uplift/denudation rate as continent-continent or arc-continent collision. It should be also highlighted that such high denudation rates can be attained within a few million years from the initiation of collision zones.

Another notable point is that these high denudation rates are related to tectonic uplift driven by faulting. The northern Akaishi Range has been uplifted mainly by the ISTL-FZ. The Kiso Range is also uplifted by marginal faults on the eastern and western sides [Sueoka et al., 2012]. The Hida Range results in at least two uplift episodes: the isostatic uplift related to volcanism and a crustal thickening at 2.7-1.5 Ma; and the tectonic uplift associated with a reverse faulting since $~ 1.3 \mathrm{Ma}$ [e.g., Oikawa, 2003; Harayama et al., 2003]. The high denudation rates estimated by Bando et al. [2003] are thought to reflect mainly the latter episode. Although the uplift mechanism of the southern Akaishi Range is not specified, the Fujikawa Kako Fault Zone is among the potential candidates. Therefore, it should be highlighted that faulting can serve as a primary driving force of a topographic relief growth at the earliest stage of the orogeny although it is known that the isostatic uplift is the key factor for sustaining the elevation of an orogen once topographic relief has been achieved [e.g., Ikeda, 1990; Braun and Robert, 2005].

\section{Conclusions}

On the basis of low-temperature thermochronology data, zircon $\mathrm{U}-\mathrm{Pb}$ ages, and thermo-kinematic modeling, the uplift and denudation history of the northern Akaishi Rangehas beenreconstructed.The thermochronometric ages get younger toward east on the western side of the boundary thrust, whereas older ages were obtained between the boundary thrust and the frontal thrust.Thermo-kinematic modeling results suggest that thenorthern Akaishi Rangewas chiefly uplifted by the boundary thrust and the fault parameters were constrained to the depth of the detachment (20-22.5 km); the dip of the ramp $\tan \theta(1 / 1.5-1 / 1)$, being $\theta=34-45^{\circ}$; and the slip velocity $(5-7.5 \mathrm{~mm} / \mathrm{yr})$. Based on simple trigonometric calculations and assuming a steady-state condition from the dip and slip velocity, the bedrock uplift and denudation rates are inferred at $\sim 4 \mathrm{~mm} / \mathrm{yr}$,. The frontal thrust is thought to be formed by the front-thrust migration of the boundary thrust at a later stage.The contribution of the MTL to uplift of the northern Akaishi Range is negligible, suggesting that the uplift and denudation style of the northern Akaishi Rangecan bebest explained asa simple tilted uplift model as proposed by Sueoka et al. [2012].On the other hand, considering the difference in FT age and the active fault distribution, the mechanism and timing of the initiation of the southern Akaishi Rangeuplift might be different from that of the northern Akaishi Range. Further thermochronometric investigations are desirable for further evaluation because the difference in FT age between the two ranges may be attributable to the effect of variable apatite chlorine content. Taking into account the total denudation of several to more than $10 \mathrm{~km}$ since the initiation of the uplift, the presence of low-relief surfaces on the ridges and the relatively constant elevations of the summits should be attributed to postuplifting processes, e.g., periglacial erosion, gravitational deformation or landslides, and dynamic equilibrium between the bedrock uplift and the denudation.

\section{Acknowledgments and Data}

Yoshiki Shirahama of Tokyo University assisted with sampling.Atsumasa Okada of Ritsumeikan University, Keiji Takemura of Kyoto University, Shinji Toda of Tohoku University provided valuable advices during the study. We thank Hayato Uyeda and ananonymous reviewer for their constructive and valuable comments. This work was partially supported by a Grant-in-Aid for Scientific Research by Japan Society for the Promotion of 
Science to Hiroyuki Tsutsumi (grant no. 20650155) and Grant-in-Aid for Research by Tokyo Geographical Society to Shigeru Sueoka (research title: uplift and denudation history of the Akaishi Range based on low-temperature thermochronometric methods). The University of Melbourne thermochronology laboratory receives infrastructure support under the AuScope Program of NCRIS. The Kanto Regional Environment Office permitted us to collect rock samples in the Minami Alps National Park.Some figures in this paper were drawn by the Generic Mapping Tools (GMT [Wessel and Smith, 1991]) and 30 arc-second grid of General Bathymetric Chart of the Oceans (GEBCO).A more detailed discussion of the methodology can be found in the supportinginformation [Carlson et al., 1999; Danhara and Iwano, 2013; Evans et al., 2005; Hasebe et al., 2009; Holden and Hoffman, 2000; Orihashi et al., 2008; Pearce et al., 1997; Yoshioka et al., 2005].The data for this paper are presented in the tables and supporting information.

\section{References}

Akimoto, K. (1991), Paleoenvironmental studies of the Nishiyatsushiro and Shizukawa Groups, South Fossa-Magna region,Science Reports of the Tohoku University, 2nd Series, Geology,61, 1-102.

Akimoto, K. (1990), Geological age and paleobathymetry of the Koma Group, Yamanashi Prefecture, Central Japan (in Japanese with English abstract),Bulletin of the Earthquake Research Institute, University of Tokyo, 65, 531-539.

Amano, K. (1991), Multiple collision tectonics of the South Fossa Magna in central Japan, Modern Geology, 15, 315-329.

Angelier, J. and P. Huchon (1987), Tectonic record of convergence changes in a collision area: the Boso and Miura peninsulas, Central Japan, Earth and Planetary Science Letters, 81, 397-408.

Asano, Y., T. Takeda, Y. Yukutake, T. Miyoshi, K. Obara, and K. Kasahara (2010), Seismicvelocitystructure and seismicity along and around the Itoigawa-Shizuoka tectoniclineactivefaultsystem inferred from dataobserved at denselydistributedstations (in Japanese with English abstract), Report of the National Research Institute for Earth Science and Disaster Prevention, 77, 31-47.

Bando, M., G. Bignall, K. Sekine, and N. Tsuchiya (2003), Petrography and uplift history of the Quaternary TakidaniGranodiorite: could it have hosted a supercritical (HDR)geothermal reservoir?Journal of Volcanology and Geothermal Research,120, 215-234.

Blow, W.H. (1969), Late middle Eocene to Recent planktonic foraminiferal biostratigraphy, in Brönnimann, P. and Renz, H.H., eds., Proc. First International Conf. Planktonic Microfossils, Geneva, 1967: Leiden (E.J. Brill), 1:199-422.

Braun, J. (2003), Pecube: a new finite element code to solve the heat transport equationin three dimensions in the Earth's crust including the effects of a time-varying,finite amplitude surface topography,Computational Geosciences, 29, 787-794.

Braun, J., and X. Robert (2005), Constraints on the rate of post-orogenic erosional decay from low-temperature thermochronological data: application to the Dabie Shan, China, Earth Surface Processes and Landforms, 30, 1203-1225.

Braun, J., P. van der Beek, P. Valla, X. Robert, F. Herman, C. Glotzbach,V. Pedersen, C. Perry, T. Simon-Labric, and C. Prigent (2012), Quantifying rates of landscape 
evolution and tectonic processes bythermochronology and numerical modeling of crustal heat transport using PECUBE, Tectonophysics, 524-525, 1-28.

Carlson, W. D., R. A. Donelick, and R. A. Ketcham (1999), Variability of apatite fissiontrack annealing kinetics: I. Experimental results, American Mineralogist, 84, 12131223.

Cherniak, D. J., and E. B. Watson (2000), Pb diffusion in zircon, Chemical Geology, 172, 524.

Committee for Catalog of Quaternary Volcanoes in Japan (1999), Catalog of Quaternary Volcanoes in Japan v1.0, CD-ROM Version, The Volcanological Society of Japan.

D'AlessioM. A., A. E. Blythe, and R. Bürgmann (2003), No frictional heat along the San Gabriel fault, California: Evidence from fission-trackthermochronology, Geology, 31, 541-544, doi:10.1130/0091-7613(2003)031<0541:NFHATS>2.0.CO;2.

Danhara, T., and H. Iwano (2013), A review of the present state of the absolute calibration for zirconfission track geochronometry using the external detector method, Island Arc, 22, 264-279.

Donelick, R. A., and D. S. Miller (1991), Enhanced TINT fission track densities in low spontaneous track density apatite using ${ }^{252} \mathrm{Cf}$-derived fission fragment tracks: A model and experimental observations, Nuclear Tracks and Radiation Measurements, $18,301-307$.

Donelick, R. A., P. B. O'Sullivan, and R. A. Ketcham (2005), Apatite fission-track analysis, in Low-Temperature Thermochronology: Techniques, Interpretations, and Applications, Reviews in Mineralogy and Geochemistry, vol. 58, pp. 49-94, Mineralogical Society of America, Chantilly, Virginia, USA.

Evans, N.J., J.P.Byrne, J.T.Keegan, and L.E.Dotter (2005), Determination of uranium and thorium in zircon, apatite and fluorite: Application to laser (U-Th)/He thermochronology,Journal of Analytical Chemistry,60, 1159-1165.

Farley, K. A. (2002), (U-Th)/He dating:Techniques, calibrations, and applications, in Noble gases in geochemistry and cosmochemistry, Reviews in Mineralogy and Geochemistry, vol. 47, pp. 819-844, Mineralogical Society of America, Chantilly, Virginia, USA.

Farley, K.A., R. A. Wolf, and L. T. Silver (1996), The effects of long alpha-stopping distances on (U-Th)/He ages, Geochimica et Cosmochimica Acta, 60, 4223-4229.

Fujiwara, O., T. Sanga, and H. Ohmori (1999), Regional distribution of erosional rates over the Japanese islands (in Japanese with English abstract),Japan Nuclear Cycle Technical Review, 5, 85-93.

Galbraith, R.F. (1981), On statistical models for fission track counts,Mathematical Geology, $13,471-478$.

Galbraith, R.F. (2010) Statistics for LA-ICPMS FissionTrack Dating, Thermo2010, Glasgow.

Gleadow, A., M. Harrison, B. Kohn, R. Lugo-Zazueta, and D. Phillips (2015). The Fish Canyon Tuff: A new look at an old low-temperature thermochronology standard, Earth and Planetary Science Letters, 424, 95-108.

Green, P.F. (1981), A new look at statistics in fission-track dating,Nuclear Tracks, 5, 77-86. 
Green, P. F. (1985), Comparisonofzetacalibrationbaselinesfor fission-trackdatingofapatite, zirconandsphene, Chemical Geology (Isotope Geoscience Section), 58, 1-22.

Harayama, S. (1992), Youngest exposed granitoid pluton onEarth: cooling and rapid uplift of the Pliocene-QuaternaryTakidani Granodiorite in the Japan Alps, central Japan, Geology,20, 657-660.

Harayama, S., K. Ohyabu, Y. Miyama, H. Adachi, and R. Shukuwa (2003), Eastward tilting and uplifting after the Late Early Pleistocenein the eastern-half area of the Hida Mountain Range (in Japanese with English abstract), The Quaternary Research, 42, 127-140.

Hasebe, N., T. Tagami, and S. Nishimura (1993), Evolution of the Shimanto accretionary complex: A fission-track thermochronologic study, in Thermal evolution of the Tertiary Shimanto Belt, Southwest Japan: An Example of Ridge-Trench Interaction, Geological Society of America Special Paper, vol. 273, pp. 121-136, Geological Society of America, Boulder, Colorado, U.S.A.

Hasebe, N., T. Tagami, and S. Nishimura (1994), Towards zircon fission-track thermochronology: Reference framework for confined track length measurements, Chemical Geology (Isotope Geoscience Section), 112, 169-178.

Hasebe, N., T. Tagami, and S. Nishimura (1997), Melange-forming processes in the developmentof an accretionary prism: Evidence from fissiontrack thermochronology, JournalofGeophysicalResearch, 102, 7659-7672.

Hasebe, N., J. Barbarand, K. Jarvis, A. Carter, and A. J. Hurford (2004), Apatite fission-track chronometry using laser ablation ICP-MS,Chemical Geology, 207, 135-145.

Hasebe, N., A. Carter, A. J. Hurford, and S. Arai (2009), The effect of chemical etching on LA-ICP-MS analysis in determining uranium concentration for fission-track chronometry,Geological Society, London, Special Publications,324, 37-46.

Hasebe, N., A. Tamura, and S. Arai (2013), Zeta equivalent fission-track dating using LAICP-MS and examples with simultaneous U-Pb dating. Island Arc, 22, 280-291.

Hashima, A., T. Sato, H. Sato, K. Asao, H. Furuya, S. Yamamoto, K. Kameo, T. Miyauchi, T. Ito, N. Tsumura, and H. Kaneda (2016), Simulation of tectonic evolution of the Kanto Basin of Japan since 1 Ma due to subduction of the Pacific and Philippine Sea plates and the collision of the Izu-Bonin arc, Tectonophysics, 679, 1-14.

Hashimoto, C., Sato, T., and Matsu'ura, M. (2008), 3-D Simulation of Steady Plate Subduction with Tectonic Erosion: Current Crustal Uplift and Free-Air Gravity Anomaly in Northeast Japan, Pure and Applied Geophysics, 165, 567-583.

Herman, F., D. Seward, P. G. Valla, A. Carter, B. P. Kohn, S. Willett, and T. A. Ehlers (2013), Worldwide acceleration of mountain erosion under a cooling climate, Nature, 504, 423-426, doi:10.1038/nature12877.

Higaki, D. (1996) Linear depressions as a sign of landslides with respect to the development of channel systems (in Japanese with English abstract), Quarterly Journal of Geography (Kikan Chirigaku), 48, 33-41.

Hirakawa, K., K. Kanzawa, and I. Asakawa (1989), Description of active fault at Shimotsuburai, northeastern side of the Koma-mountains, Yamanashi Prefecture, Central Japan (in Japanese), Active Fault Research, 6, 43-46. 
Hirata, D., H. Yamashita, K. Suzuki, T. Hirataa, Y. Li, and Y. Kon (2010), Collision accretion tectonics of the Proto-Izu-Mariana arc: A review (in Japanese with English abstract), Journal of Geography (Chigaku Zasshi), 119, 1125-1160.

Holden, N. E., and D. C.Hoffman(2000), Spontaneousfission half-lives for ground-state nuclides (Technicalreport),Pure and Applied Chemistry,72, 1525-1562.

Hourigan, J.K., P. W. Reiners, and M. T. Brandon (2005), U-Th zonation dependent alphaejection in (U-Th)/He chronometry,Geochimica et Cosmochimica Acta, 69, 33493365.

Hurford, A. J., and R. T. Watkins (1987), Fission-track age of the tuffs of the Buluk member, Bakate formation, Northern Kenya: A suitable fission-track age standard, Chemical ' Geology (Isotope Geoscience Section), 66, 209-216.

Iio, Y., and Y. Kobayashi (2002), Is the plastic flow uniformly distributed below the seismogenic region?Earth Planets Space, 54, 1085-1090.

Ikeda, Y. (1983), Thrust-front migration and its mechanism: Evolution of intraplate thrust fault systems, Bulletin of the Department of Geography, University of Tokyo, 15, 125159.

Ikeda, Y. (1990), Erosion and uplift: Observational basis for modeling mountain building processes (in Japanese with English abstract), Zisin (Journal of the Seismological Society of Japan. 2nd ser.), 43, 137-152.

Ikeda, Y. (1996), Implications of active fault study for the present-day tectonics of the Japan arc (in Japanese with English abstract),Active Fault Research, 15, 93-99.

Ikeda, Y., T. Iwasaki, K. Kano, T. Ito, H. Sato, M. Tajikara, S. Kikuchi, M. Higashinaka, T. Kozawa, and T. Kawanaka (2009), Active nappe with a high slip rate: Seismic and gravity profiling across the southern part of the Itoigawa-Shizuoka Tectonic Line, central Japan,Tectonophysics, 472, 72-85.

Ishida, S., T. Makinouchi, A. Nishimura, K. Takemura, T. Danhara, K. Nishiyama, and A. Hayashida (1980), Middle Pleistocene of Kakegawa District, Central Japan (in Japanese with English abstract),The Quaternary Research, 19, 133-147.

Isozaki, Y. (1996), Anatomy and genesis of a subduction-related orogen: A new view of geotectonic subdivision and evolution of the Japanese Islands, The Island Arc, 5, 289320.

Isozaki, Y., K. Aoki, T. Nakama and S. Yanai (2010), New insight into a subduction-related orogen: A reappraisal of the geotectonicframework and evolution of the Japanese Islands, Gondwana Research,18, 82-105.

Ito, H., R. B. Sorkhabi, T. Tagami, and S. Nishimura (1989), Tectonic history of granitic bodies in the South Fossa Magna region, central Japan: new evidence from fissiontrack analysis of zircon,Tectonophysics, 166, 331-344.

Ito, H., R. Yamada, A. Tamura, S. Arai, K. Horie, and T. Hokada (2013), Earth's youngest exposed granite and its tectonic implications: the 10-0.8 Ma Kurobegawa Granite, Scientific Reports, 3, 1306, doi: 10.1038/srep01306.

Iwano, H., Y. Orihashi, T. Hirata, M. Ogasawara, T. Danhara, K. Horie, N. Hasebe, S. Sueoka, A. Tamura, Y. Hayasaka, A. Katsube, H. Ito, K. Tani, J.-I. Kimura, Q. Chang, Y. Kouchi, Y. Haruta, and K. Yamamoto (2013), An inter-laboratory 
evaluation of OD-3 zircon for use as a secondaryU-Pb dating standard, Island Arc, $22,382-394$.

Kaizuka, S., andK. Chinzei (1986), Nature in Japan, Vol. 2, Iwanami Shoten Co., Ltd., Tokyo, Japan (in Japanese).

Kanemoto, T. and T. Otsuka (2000), Illite crystallinity and low-grade metamorphism of the Sanbagawa, Chichibu and Shimanto Belts in the south area of Lake Suwa, central Japan (in Japanese with English abstract), Journal of the Faculty of Science, Shinshu University,35, 11-29.

Kano, K. (2002), Re-arrangement of the shallow-level structure of Southwest Japan Arc due to the collision of the Izu-Bonin Arc (in Japanese with English abstract),Bulletin of

the Earthquake Research Institute, University of Tokyo, 77, 231-248.

Kano, K., K. Ito, and T. Takagawa (2012), Diagenesis and very-low grade metamorphism of the Chichibu and Shimanto Belts in the Akaishi Mountains, Southwest Japan: an illite crystallinity study, Abstract of Annual Meeting of the Geological Society of Japan, R13-O-5.

Kano, K., I. Suzuki, and H. Kitazato (1985), Paleogeography of the Shizukawa Group in the Nakatomi area in the upper reaches of Fuji River, South Fossa Magna region, central Japan (in Japanese with English abstract),Geoscience Reports of Shizuoka University, $11,135-153$.

Katsumata, A. (2010), Depth of the Moho discontinuity beneath the Japanese islandsestimated by traveltime analysis, Journal of Geophysical Research, 115, B04303, doi:10.1029/2008JB005864,

Ketcham, R. A. (2005), Forward and inverse modeling of low-temperature thermochronometry data, in Low-Temperature Thermochronology: Techniques, Interpretations, and Applications, Reviews in Mineralogy and Geochemistry, vol. 58, pp. 275-314, Mineralogical Society of America, Chantilly, Virginia, USA.

Kimura, G. (1996), Collision orogeny at arc-arc junctions in the Japanese Islands, The Island Arc,5, 262-275.

Kimura, J. I., R. J. Stern, and T. Yoshida (2005), Reinitiation of subduction and magmatic responses in SW Japan duringNeogene time, Geological Society of America Bulletin, 117, 969-986, doi: 10.1130/B25565.1.

Korup, O., Y. Hayakawa, A. T. Codilean, Y. Matsushi, H. Saito,T. Oguchi and H. Matsuzaki (2014), Japan's sediment flux to the Pacific Ocean revisited, Earth-Science Reviews, 135, 1-16.

Kudo, T., A. Yamaji, M. Furumoto, and T. Nagao (2001), Effective elastic thickness of island arc lithosphere under Japan, The Island Arc,10, 135-144.

Kumamoto, T., and Y. Ikeda (1993), Fault geometry and net slip of low angle thrust faults in the Kofu basin, central Japan (in Japanese with English abstract), Zisin, Second Series, 46, 245-258.

Ludwig, K.R. (2003), User's manual for Isoplot 3.00: A geochronological toolkit for Microsoft excel. Berkeley Geochronology Center Special Publication 4.

Maruyama, T., and M. Saito (2007), Paleoseismological investigation of the Fujikawa-kako fault zone, Shizuoka Prefecture, central Japan (in Japanese with English abstract), Annual Report on Active Fault and Paleoearthquake Researches, 7, 129-155. 
Matsuda, T. (1978), Collision of the Izu-Bonin arc with central Honshu: Cenozoic tectonics of the Fossa Magna, Japan,Journal of Physics of the Earth, 26, Suppl., S409-S421.

Matsuda, T. (1984), Southern Fossa Magna: Development history of its curved structures. 127-146. In Huzita K. (ed.) "Mobile Belts in Asia: Between the Himalaya and the Japan Trench", Kaibundo, Tokyo, 400p.

Matsuoka, N. (1985), Rock control on the distribution of linear depressions on the main divide of Akaishi Range, southern Japanese Alps (in Japanese with English abstract), Geographical Review of Japan, 58A, 411-427.

Matsushi, Y., H. Matsuzaki, and H. Makino (2014), Testing models of landform evolution by determining the denudation rates of mountainous watersheds using terrestrial cosmogenic nuclides (in Japanese with English abstract), Transactions, Japanese Geomorphological Union, 35, 165-185.

Matsushima, N. (1995),Morphogenetic history of the Ina basin (in Japanese with English abstract).Research Report of the Iida City Museum, Vol. 3, Iida City Museum, Iida, Japan.

Miura, D., R. Hataya, K. Miyakoshi, D. Inoue, M. Omata, T. Sasaki, Y. Kawasaki, K. Sato, A. Miyawaki, T. Tanaka, and R. Miyawaki (2004), Reappraisal for recent faulting history of the Hakushu fault, the southern part of the Itoigawa-Shizuoka Tectonic Line, central Japan (in Japanese with English abstract), Journal of the Geological Society of Japan, 110, 255-270.

Miyazaki, S., and Heki, K. (2001), Crustal velocity field of southwest Japan: Subduction and arc-arc collision. JournalofGeophysicalResearch, 106, 4305-4326.

Mizumoto, T., H. Goto, T. Nakata, T. Matsuda, M. Tajikara, and R. S. Matsu'ura (2016), Tectonic landforms associated with recent activities of the Minobu fault in the Fujikawa Valley and its implications, South Fossa Magna, Central Japan (in Japanese with English abstract). Active Fault Research, 44, 9-21.

Mokudai, K., and M. Chigira (2004), Geomorphic features and processes of gravitational mountain deformation in the area from Mt. Yambushi to Oya-kuzure, central Japan,Geographical Review of Japan, 77, 55-76.

Montgomery, D. R., and M. T. Brandon (2002), Topographic controls on erosion rates in tectonically active mountain ranges, Earth and Planetary Science Letters, 201, 481489.

Moriyama, A. (1990a), When were mountains uplifted?: The uplift age of mountains in central Japan, Geographical Reports of Tokyo Metropolitan University, 25, 21-42.

Moriyama, A. (1990b), Uplift age of mountains in Central Japan (in Japanese),inTectonic Landforms, edited by N. Yonekura, A. Okada and A. Moriyama, pp. 87-109, Kokon Shoin Co., Ltd., Tokyo, Japan.

Moriyama, A., and K. Mitsuno (1989), The mountain landforms and crustal movement in the upper Kiso river drainage basin (in Japanese with English abstract),Bulletin of Aichi University of Education, Natural Sciences,38, 1-19.

Murakami, M., and T. Tagami (2004),Dating pseudotachylyte of the Nojima fault using the zircon fission-track method, Geophysical Research Letters, 31,L12604, doi:10.1029/2004GL020211. 
Muto, T. (1985), Fossil submarine channels found from the Pleistocene strata in the Kakegawa district, Shizuoka Prefecture, central Japan (in Japanese with English abstract), The Journal of the Geological Society of Japan, 91, 439-452.

Nakama, T., T. Hirata, S. Otoh, K. Aoki, S. Yanai, and S. Maruyama (2010), Paleogeography of the Japanese Islands:Age Spectra of Detrital Zircon and Provenance History of the Orogen (in Japanese with English abstract), Journal of Geography (Chigaku Zasshi), $119,1161-1172$.

Nakata, T., and T. Imaizumi (2002), Digital Active Fault Map of Japan (in Japanese with English Abstract). University of Tokyo Press, Tokyo, Japan.

Ohmori, H. (1978), Relief structure of the Japanese mountains and their stages in geomorphic development, Bulletin of the Department of Geography, University of Tokyo, 10, 3185.

Ohmori, H. (1985), A comparison between the Davisianscheme and landform development by concurrent tectonicsand denudation, Bulletin of the Department of Geography, University of Tokyo, 17, 19-28.

Ohmori, H. (1987), Mean Quaternary uplift rates in the central Japanese mountains estimated by means of geomorphological analysis,Bulletin of the Department of Geography, University of Tokyo, 19, 29-36.

Oikawa, T. (2003), The spatial and temporalrelationship between uplifting and magmatism in the Hida Mountain Range, central Japan (in Japanese with English abstract), The Quaternary Research, 42, 141-156.

Orihashi, Y., S. Nakai, and T. Hirata (2008), U-Pb age determination for seven standard zircons using inductively coupled plasma-mass spectrometry coupled with frequency quintupled Nd-YAG $(\lambda=213 \mathrm{~nm})$ laser ablation system: Comparison with LA-ICPMS zircon analyses with a NIST glass reference material,Resource Geology,58, 101123.

Panayotopoulos, Y., N. Hirata, H. Sato, T. Iwasaki, A. Kato, K. Imanishi, Y. Kuwahara, and I. Cho (2010), Seismicity and crustal structure in the vicinity of the southernItoigawaShizuoka Tectonic Line,Earth, Planets and Space, 62, 223-235.

Pearce, N.J.G., W. T. Perkins, J. A. Westgate, M. P. Gorton, S. E. Jackson, C. R. Neal, and S. M. Chenery (1997), A compilation of new and published major and trace element data for NIST SRM 610 and NIST SRM 612 glass reference materials,Geostandards Newsletter,21, 115-144.

Reiners, P. W. (2005), Zircon (U-Th)/He thermochronometry, in Low-Temperature Thermochronology: Techniques, Interpretations, and Applications, Reviews in Mineralogy and Geochemistry, vol. 58, pp. 151-179, Mineralogical Society of America, Chantilly, Virginia, USA.

Reiners, P. W., and M. T. Brandon (2006), Using thermochronology to understand orogenic erosion, Annual Review of Earth and Planetary Sciences, 34, 419-466, doi: 10.1146/annurev.earth.34.031405.125202.

Research Group for Quaternary Tectonic Map (1968), Quaternary tectonic map of Japan (in Japanese with English abstract),The Quaternary Research, 7, 182-187.

Sato, K., K. Shibata, and S. Uchimi (1989), K-Ar ages and cooling history of the Kaikomagatake granitoid pluton, and their bearing on tectonic evolution of the 
Akaishi Mountains, central Japan (in Japanese with English abstract),The Journal of the Geological Society of Japan, 95, 33-44.

Sawa, S. (1985), Active faults in central part of the Itoigawa-Shizuoka tectonic line, central Japan (in Japanese with English abstract), Geographical Review of Japan, 58A, 695714.

Shiba, M., M. Okubo, S. Kasahara, G. Yamamoto, S. Kobayashi, and Suruga Bay Collaborative Research Group (1990), Stratigraphy and geologic structure of the Ihara Group, Pleistocene around the lower Fuji River, Shizuoka Prefecture (in Japanese with English abstract),Earth Science (Chikyu Kagaku), 44, 205-223.

Shuster, D. L., R. M. Flowers, and K. A. Farley (2006), The influence of natural radiation " damage on heliumdiffusion kinetics in apatite, Earth and Planetary Science Letters, 249, 148-161.

Southern Alps World Natural Heritage Registration Promotion Meeting (2010) "The Southern Alps Arts and Sciences General Remarks", 130p (in Japanese), http://www.city.shizuoka.jp/000_002707.html.

Sueoka, S., B. P. Kohn, T. Tagami, H. Tsutsumi, N. Hasebe, A. Tamura, and S. Arai (2012), Denudation history of the Kiso Range, central Japan, and its tectonic implications: Constraints from low-temperature thermochronology, The Island Arc, 21, 32-52.

Sugai, T. (1990), The origin and geomorphic characteristics of the erosional low-relief surfaces in the Akaishi Mountains and the southern part of the Mikawa plateau, central Japan (in Japanese with English abstract), Geographical Review of Japan, 63A, 793-813.

Sugai, T. (1992), Low-relief erosion surfaces formed by periglacial processes in the alpine zone of the Akaishi Mountains, central Japan: Quantitative analysis based on the process-response model (in Japanese with English abstract), Geographical Review of Japan, 65A, 168-179.

Sugai, T. (1995), Origin of the low-relief surfaces on ridges in the Kiso Range and northern part of the Mino-Mikawa plateau, central Japan (in Japanese with English abstract), Proceedings of the Department of Humanities, College of General Education, University of Tokyo, Series of Human Geography, 7, 1-40.

Suganuma, Y., T. Suzuki, H. Yamazaki, and T. Kikuchi (2003), Chrono-stratigraphy of the Ina Group, central Japan, based on correlation of volcanic ash layers with Pleistocene widespread tephras (in Japanese with English abstract), The Quaternary Research, 42, 321-334.

Tagami, T., and K. Shibata (1993), Fission track ages on some Ryoke granitic rocks along the Median Tectonic Line, Southwest Japan,Geochemical Journal, 27, 403-406.

Tagami, T., N. Lal, R. B. Sorkhabi, and S. Nishimura (1988a), Fission track thermochronologic analysis of the Ryoke Belt and the Median Tectonic Line, southwest Japan,Journal of Geophysical Research, 93, 13705-13715.

Tagami, T., N. Lal, R. B. Sorkhabi, H. Ito, and S. Nishimura (1988b), Fission track dating using external detector method: A laboratory procedure,Memoirs of the Faculty of Science, Kyoto University, Series of Geology and Mineralogy, 53, 1-30. 
Tajikara, M. (2002), Tectonic landforms and Quaternary activity along the southern part of the Itoigawa-Shizuoka tectonic line (Hakushu-Nirasaki district), central Japan (in Japanese with English abstract), Active Fault Research, 21, 33-49.

Taira, A., S. Saito, A. Aoike, S. Morita, H. Tokuyama, K. Suyehiro, N. Takahashi, M. Shinohara, S. Kiyokawa, J. Naka, and A. Klaus (1998), Nature and growth rate of the Northern Izu-Bonin (Ogasawara) arc crustand their implications for continental crust formation, The Island Arc, 7, 395-407.

Takahashi, M. (2006), Tectonic development of the Japanese Islands controlled by Philippine Sea Plate motion (in Japanese with English abstract), Journal of Geogrphy (Chigaku Zasshi), 115, 116-123.

Tanaka, M. (1982), A map of regional denudation rate in Japanese mountains, Transactions, JapanGeomorphological Union, 3, 159-167.

Tanaka, A., M. Yamano, Y. Yano, and M. Sasada (2004), Geothermal gradient data in and around Japan, digital geoscience map DGM P-5. Geological Survey of Japan, Tsukuba.

Tani, K., D. J. Dunkley, J. Kimura, R. J. Wysoczanski, K. Yamada, and Y. Tatsumi (2010), Syncollisional rapid granitic magma formation in an arc-arc collision zone: Evidence from the Tanzawa plutonic complex, Japan, Geology, 38, 215-218.

Townend, J. and M. D. Zoback (2006), Stress, strain, and mountain building in central Japan. Journal of Geophysical Research, 111, B03411, doi:10.1029/2005JB003759.

Tsutsumi, H., Sato, K., and Yamaji, A. (2012), Stability of the regional stress field in central Japan during the late Quaternary inferred from the stress inversion of the active fault data, Geophysical Research Letters, 39, L23303, doi:10.1029/2012GL054094.

The Research Group for Active Faults of Japan (1991), Active Faults in Japan: Sheet Maps and Inventories (Rivised Edition) (in Japanese with English abstract). University of Tokyo Press, Tokyo.

Umeda, K., R. Komatsu, and N. Nakatsuka (1999), Geothermal structure based on temperature logging data of boreholes in Japan (in Japanese with English abstract), Japan Nuclear Cycle Technical Review, 2, 29-36.

Wakita, K., T. Igawa, and S. Takarada (2009), Seamless Geological Map of Japan at a Scale of 1:200,000 DVD Edition. Digital Geoscience Map DGM G-16, Geological Society of Japan, AIST, Tsukuba, Japan.

Wallis, S., Y. Moriyama, and T. Tagami (2004), Exhumation rates and age of metamorphism in the Sanbagawa belt:new constraints from zircon fission track analysis, Journal of metamorphic Geology, 22, 17-24.

Wessel, P., and W. H. F. Smith (1991), Free software helps map and display data,Eos, Transactions, American Geophysical Union, 72, 441.

Willett, S. D. (1999), Orogeny and orography: The effects of erosion on the structure of mountain belts,Journal of Geophysical Research,104, 28957-28981.

Yamada, R., T. Tagami, and S. Nishimura (1995), Confined fission-track length measurement of zircon: assessment of factors affecting the paleotemperature estimate, Chemical Geology (Isotope Geoscience Section), 119, 293-306. 
Yamada, K., and T. Tagami (2008), Postcollisional exhumation history of the Tanzawa Tonalite Complex, inferred from (U-Th)/He thermochronology and fission track analysis, Journal of Geophysical Research, 113, B03402.

Yamagiwa, A. (1998MS), Uplift-cooling History of Akaishi Mountainland: FT Thermochronological Study,Master Thesis of Graduate School of Science, Kyoto University.

Yamagiwa, A., N. Hasebe, and T. Tagami (1997), FT age of Shimanto belt, eastern part of Akaishi Mountainland (in Japanese),Fission Track News Letter, 10, 47-50.

Yamamoto, G., and M. Shimazu (1998), Petrochemistry of volcanic rocks of the Nishiyatsushiro Group in the South Fossa Magna (in Japanese with English abstract), Earth Science (Chikyu Kagaku), 52, 171-187.

Yamamoto, S., Senshu, H., Rino, S., Omori, S., and Maruyama, S. (2009), Granite subduction: Arc subduction, tectonic erosion and sediment subduction, Gondwana Research,15, 443-453.

Yamazaki, H. (1992), Tectonics of a plate collision along the northern margin of Izu peninsula, centralJapan,Bulletin of the Geological Survey of Japan, 43, 603-657.

Yanai, S., K. Aoki, and Y. Akahori (2010), Opening of Japan Sea and major tectonic lines of Japan: MTL, TTL and Fossa Magna (in Japanese with English abstract),Journal of Geography (Chigaku Zasshi),119, 1079-1124.

Yonekura, N., S. Kaizuka, M. Nogami, and K. Chinzei (2001), Introduction to Japanesegeomorphology. Regional Geomorphology of the Japanese Islands, 1. Universityof Tokyo Press, Tokyo, p. 349 (in Japanese).

Yoshikawa, T. (1974), Denudation and tectonic movementin contemporary Japan,Bulletin of the Departmentof Geography, University of Tokyo,6, 1-14.

Yoshikawa, T. (1984), Geomorphology of tectonically active and intensely denuded regions (in Japanese with English abstract), Geographical Review of Japan,57A, 691-702.

Yoshioka, T., H. Iwano, and T. Danhara (2005), Spontaneous fission decay constant of 238Udetermined by SSNTD method using CR-39 andDAP plates,Nuclear Instruments and Methods inPhysics Research,A555, 386-395. 


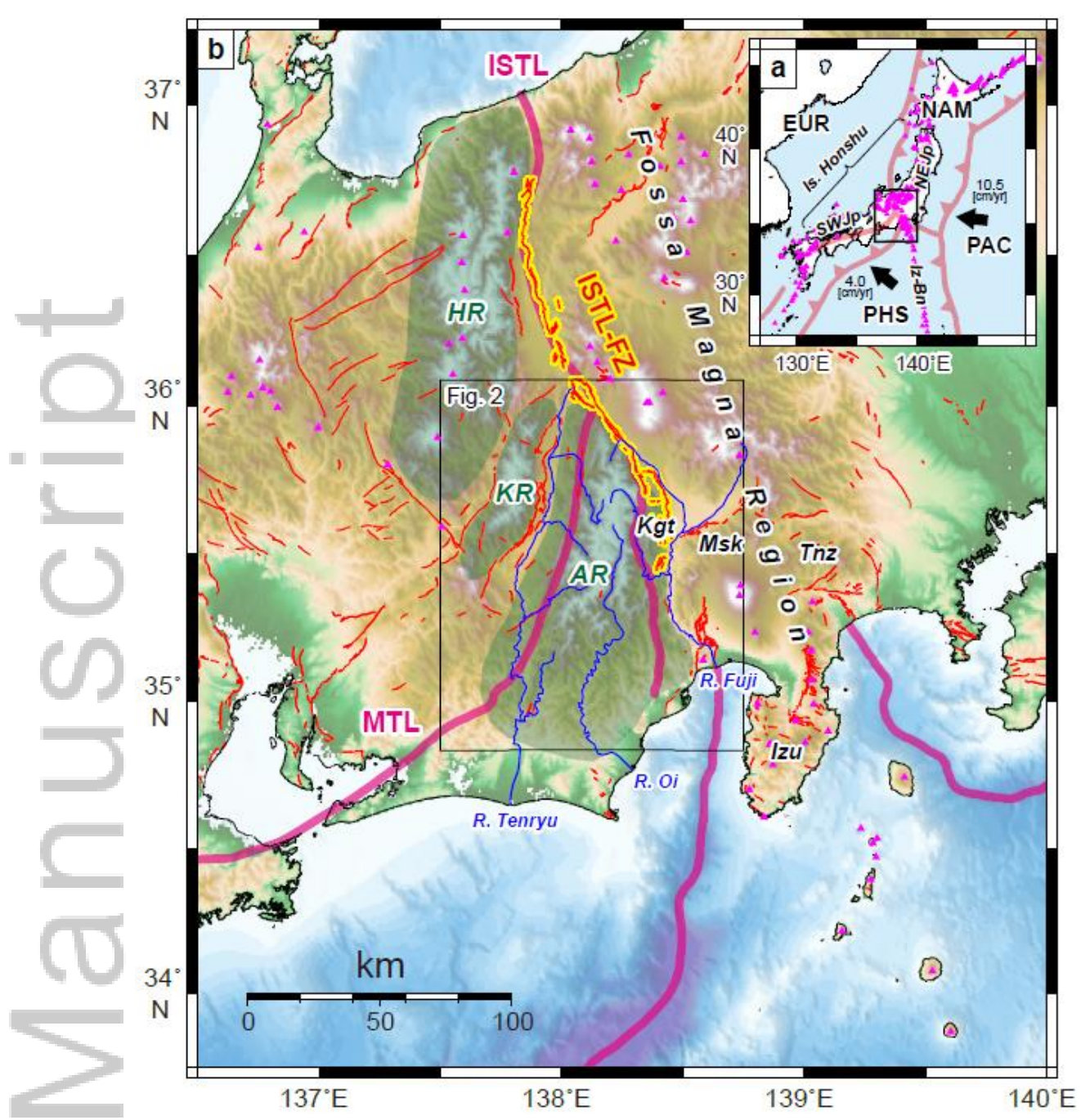

Figure 1.Map of the study area. Pink triangles indicate Quaternary volcanoes from Committee for Catalog of Quaternary Volcanoes in Japan[1999], red lines indicate active fault traces from Nakata and Imaizumi[2002], light red solid lines indicate plate boundaries and major tectonic lines (see also following figures). (a) Tectonic setting around the Japanese Islands. Triangles along the plate boundaries indicate subduction directions. The directions and rates of the moving the Philippine Sea and Pacific plates are from Isozaki [1996]. PHS: Phillippine Sea plate; EUR: Eurasian plate; PAC: Pacific plate; NAM: North American plate; NEJp: Northeast Japan arc; SWJp: Southwest Japan arc; and Iz-Bn: Izu-Bonin arc. (b) Shaded relief map of central Japan. Blue lines indicate major rivers in and around the Akaishi Range. The Northeast and Southwest Japan arcs are divided by the Fossa Magna region, which lies to the east of the Itoigawa-Shizuoka Tectonic Line (ISTL). Note the 3,000m-high Japan Alps located to the west of the ISTL, i.e., Hida Range (HR), Kiso Range (KR), and Akaishi Range (AR). Crustal blocks of the Izu-Bonin arc have collided with the South Fossa Magna region; the Kushigatayama block (Kgt) collided at 15-13 Ma, the Misaka block (Msk) at 13-8 Ma, the Tanzawa block (Tnz) at 8-5 Ma, and the Izu block since 1 Ma [e.g., Amano, 1991; Hirata et al., 2010]. 


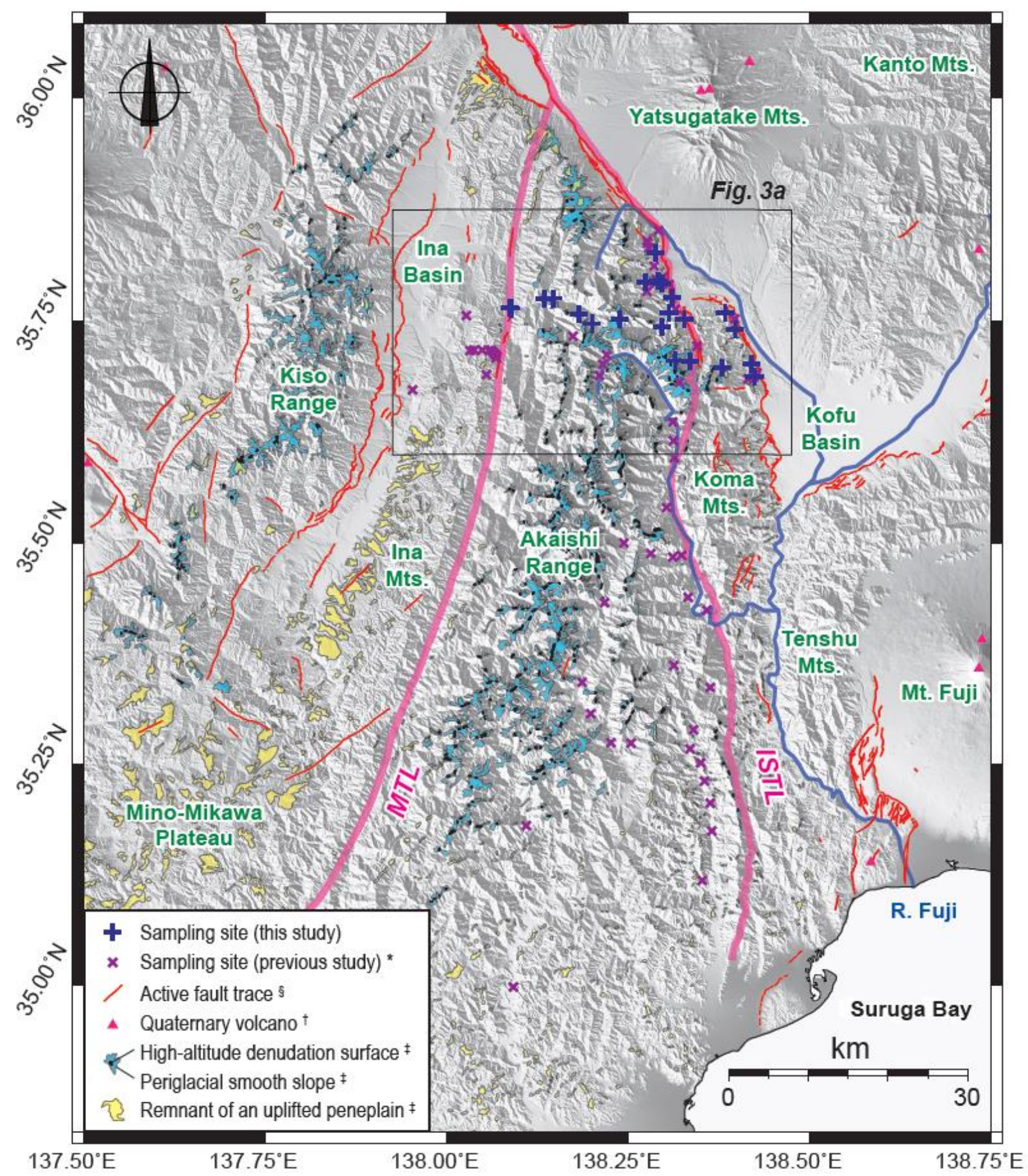

Figure2. Shaded relief map of the study area."Akaishi Range" is used in a restricted sense here. Next symbols indicate: * Sample sites for previously reported FT ages by Tagami et al. [1988a], Ito et al. [1989], Tagami and Shibata [1993], Yamagiwa et al. [1997], and Yamagiwa [1998MS]; § Active fault traces from Nakata and Imaizumi [2002]; $\uparrow$ Quaternary volcanoes from Committee for Catalog of Quaternary Volcanoes in Japan[1999]; and\$ Distribution and classification of low-relief eroded surfaces from Sugai [1990, 1995].ISTL: Itoigawa-Shizuoka Tectonic Line; MTL: Median Tectonic Line. 

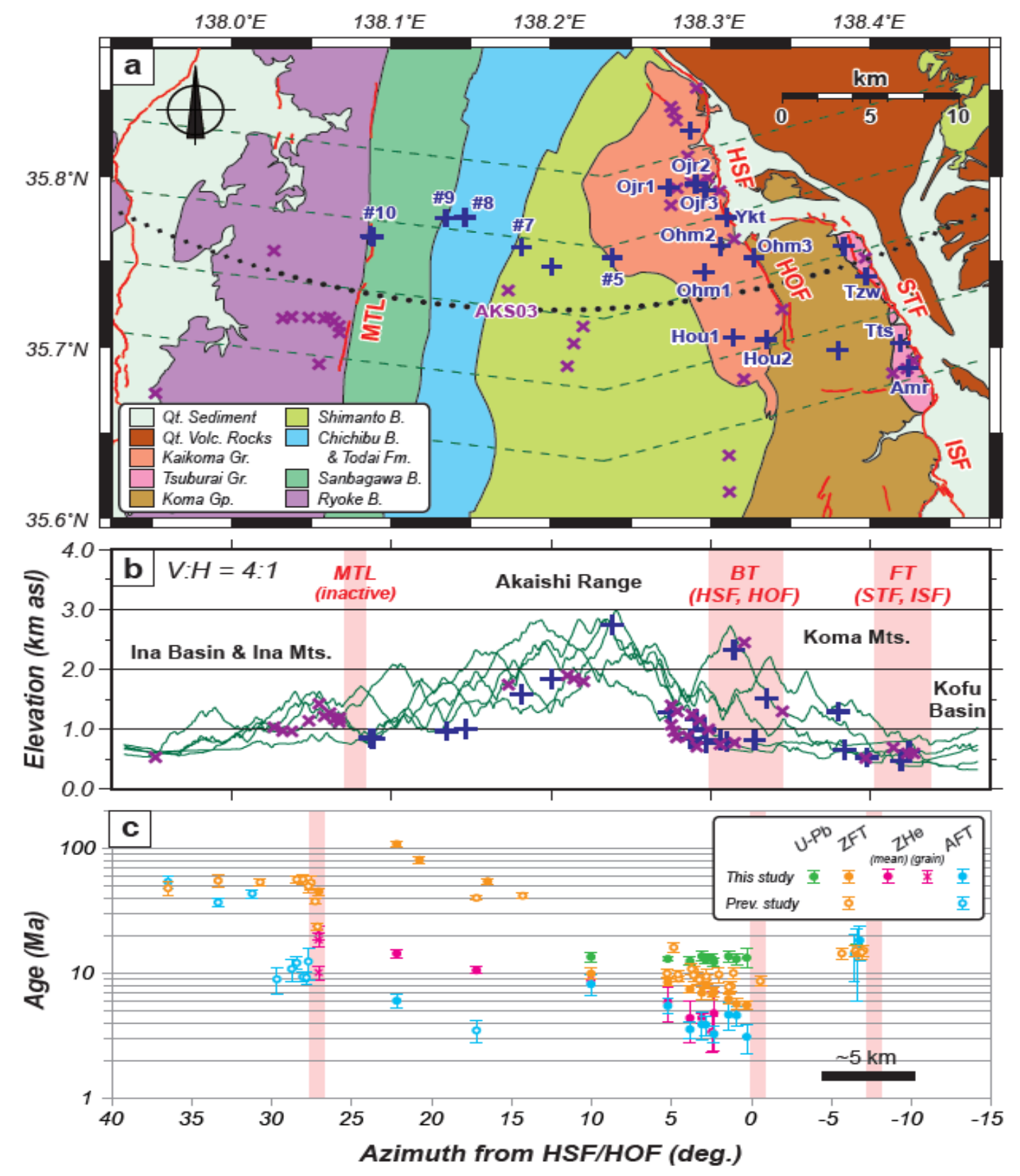

Figure3. (a) Geologic map of the study area and samplelocations. The geologic map is simplified according toWakita et al. [2009].Active fault traces considering the studies ofNakata and Imaizumi [2002].MTL: Median Tectonic Line; HSF: Hakushu fault; HOF: Hoosan fault; STF: Shimotsuburai fault; and ISF: Ichinose fault.HSF and HOF constitute the boundary thrust (BT), while STF and ISF constitute the frontal thrust (FT).Dashed green lines are profiles of topographic cross-sections shown in Figure 3b, whereas a dotted black line is a projection line of thermochronometric ages shown in Figure 3c. (b) Topographic crosssections across the northern Akaishi Range.Sampling localities shown in Figure $3 a$ are also projected."Akaishi Range" is used in a restricted sense here. (c) Thermochronometric ages projected ontothe projection line shown in Figure 3a, namely, a circle whose center is at $\left(138.2000^{\circ} \mathrm{E}, 36.1667^{\circ} \mathrm{N}\right)$. The plotted ages are obtained at localities shown in Figure 3a, which are from Tagami et al. [1988a], Ito et al. [1989], Tagami and Shibata [1993], Yamagiwa et al. [1997], Yamagiwa [1998MS], and this study.Error bars are $\pm 2 \sigma$ for ZFT, AFT, and zircon $\mathrm{U}-\mathrm{Pb}$ ages, while a $\pm 95 \%$ confidencelevelcorresponds for $\mathrm{ZHe}$ ages.ZHe grain ages $( \pm 2 \sigma)$ of $\# 10$ are plotted instead of the weighted mean age. 

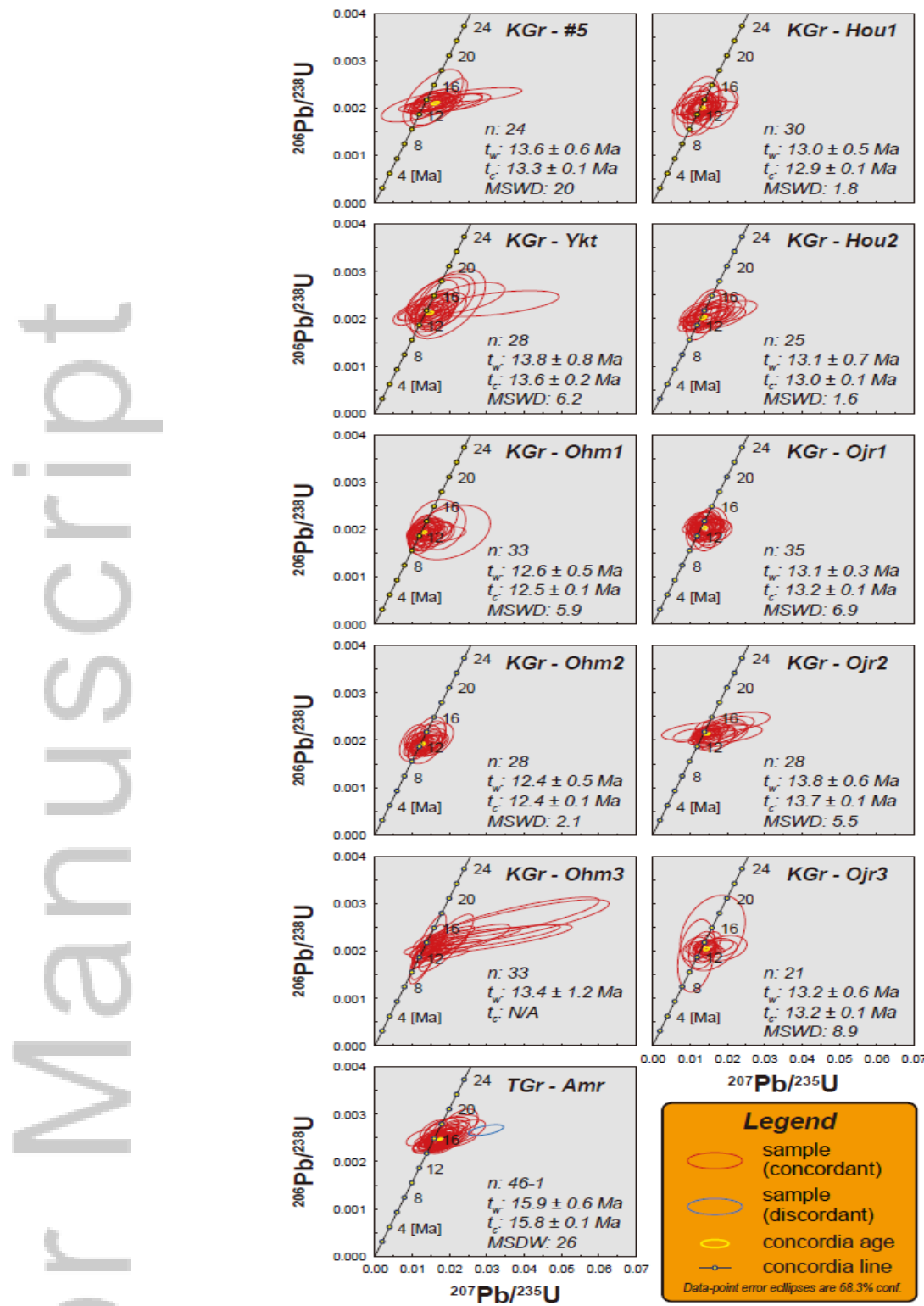

Figure4. Concordia plots of zircon $\mathrm{U}-\mathrm{Pb}$ grain ages.Error eclipses present $\pm 1 \sigma$ ranges.Markers of the Concordia lines are plotted at intervals of $2 \mathrm{Ma}$. Number of the measurement spots $(\mathrm{n}),{ }^{238} \mathrm{U}-{ }^{206} \mathrm{~Pb}$ age $\pm 1 \sigma\left(t_{\mathrm{w}}\right.$ : weighted mean age, $t_{\mathrm{c}}$ : concordia age $)$, and mean square weighted deviation of concordance (MSWD)are also indicated; 46 spots were measured for Amr, but 45 spots, except for a discordant datum, were adopted for the weighted mean age calculation.KGr: Kaikoma granite; TGr: Tsuburai granite.Detailed U-Pb parameters are shown in Table S1. 


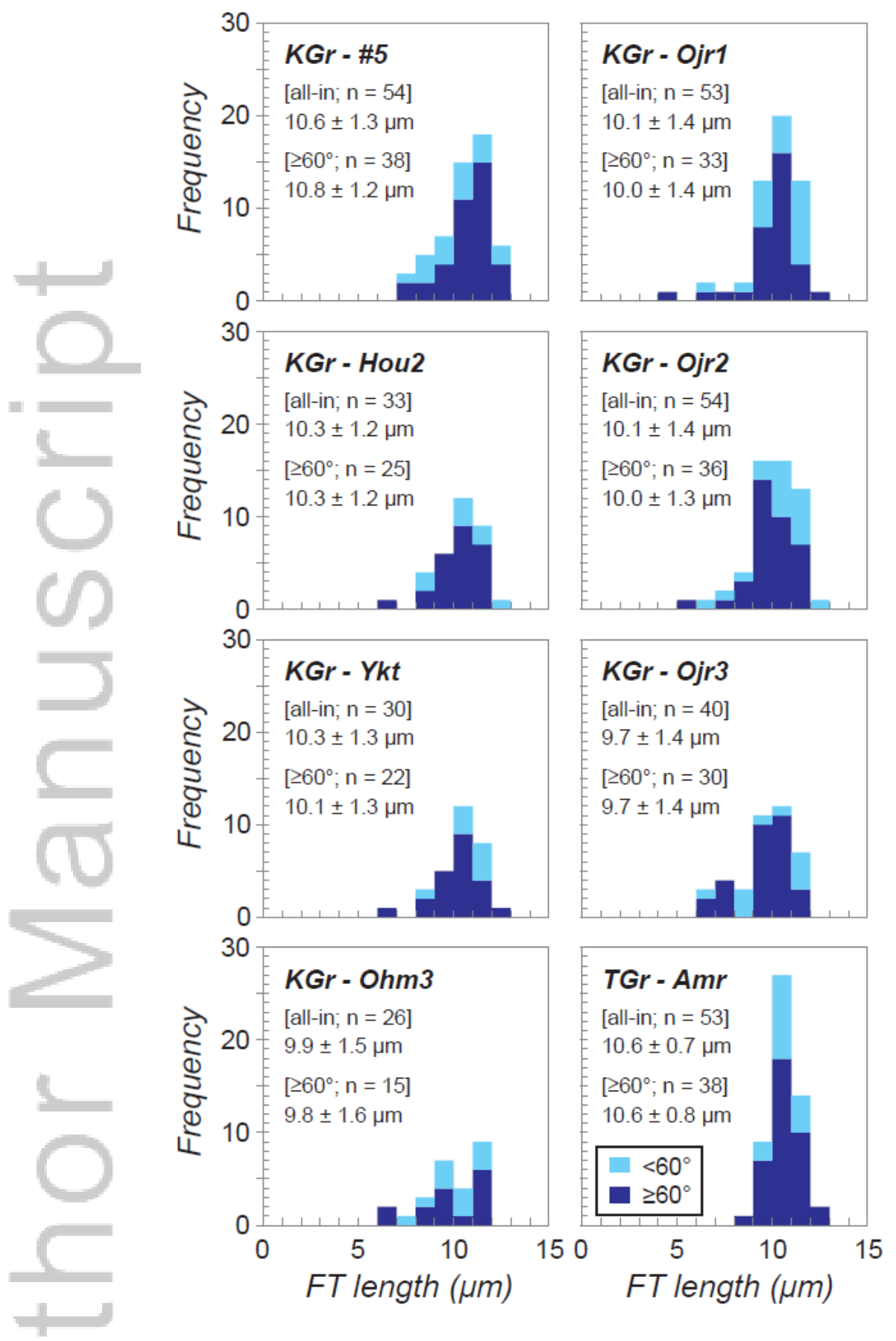

Figure5. ZFT length histograms.Mean lengths $\pm 1 \sigma$ are also shown.n $=$ number of FT lengths measured.KGr: Kaikoma granite; TGr: Tsuburai granite.Note that the track-length distribution is shown with different patterns for tracks marking azimuthangles thathigher (dark blue column) and lower (light blue column) than $60^{\circ}$ to the crystallographic $c$-axis, because track lengths in zircon are dependent on etching andannealing properties that show an angular variation [Hasebe et al., 1994; Yamada et al., 1995]. 

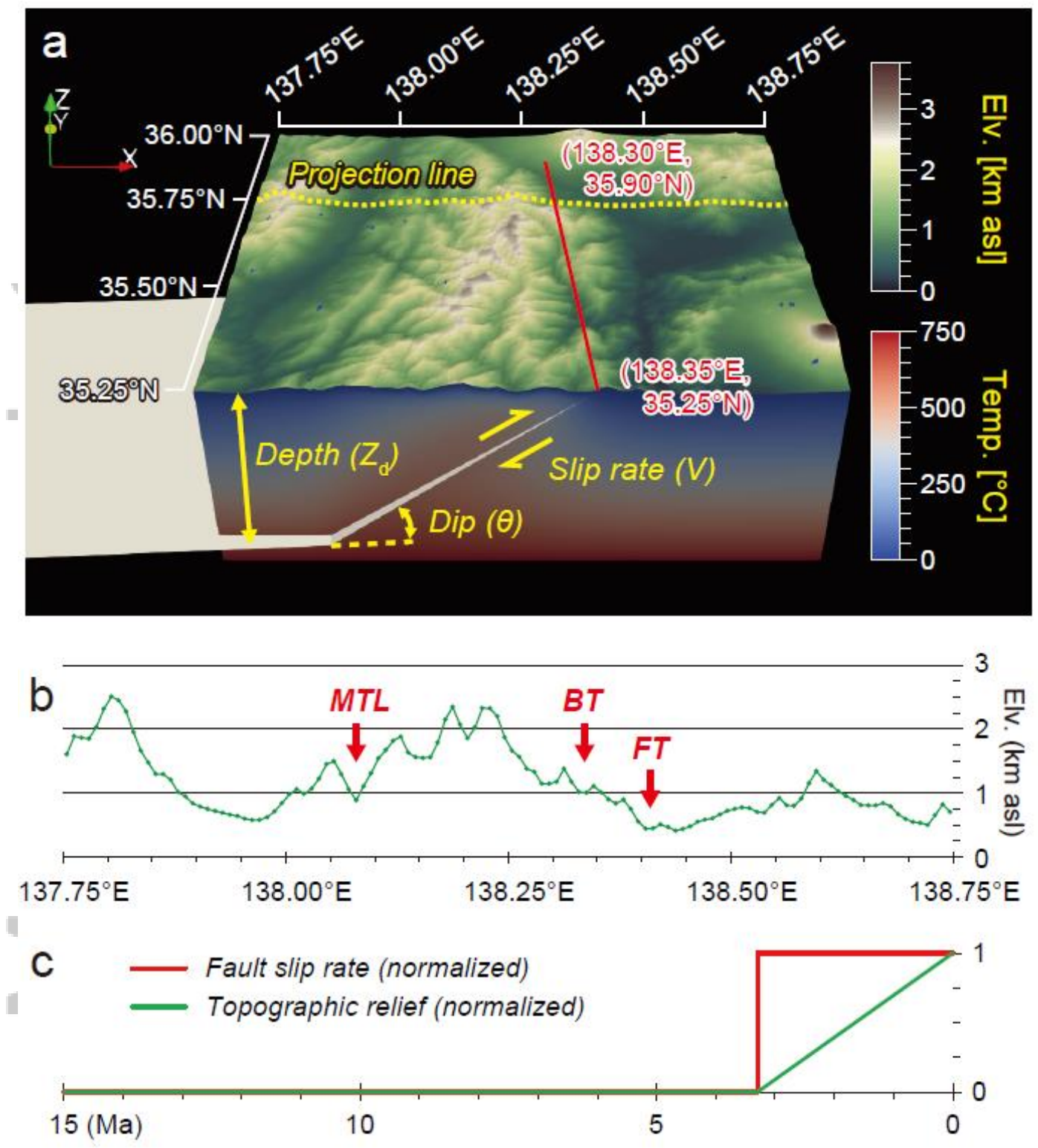

Figure6. Thermo-kinematic modeling of the northern Akaishi Rangeby using Pecube v.3 [Braun et al., 2012].(a) Schematic diagram of the model setting.Fault consists of a rectangular ramp and detachment.Slip rate $(V)$, dip of $\operatorname{ramp}(\theta)$, and depth of detachment $\left(Z_{\mathrm{d}}\right)$ are variable.The horizontal distance from the surface fault trace to the end of the detachment is constantand equal to $200 \mathrm{~km}$. The projection line is a latitude line of $35.75^{\circ} \mathrm{N}$, along which the calculated ages are compared to the observed ages (Tables 5-6, Figure 7).(b) Topographic cross-section along the projection line drawn by using SRTM3. The approximate locations of the MTL, boundary thrust (BT), and frontal thrust (FT) along the profile are also shown.(c) Modeled tectonic scenario.Calculation duration is from $15 \mathrm{Ma}$ to $0 \mathrm{Ma}$.Constant fault activity and relief change start at 3.3 Ma and continue until $0 \mathrm{Ma}$. 
(a)

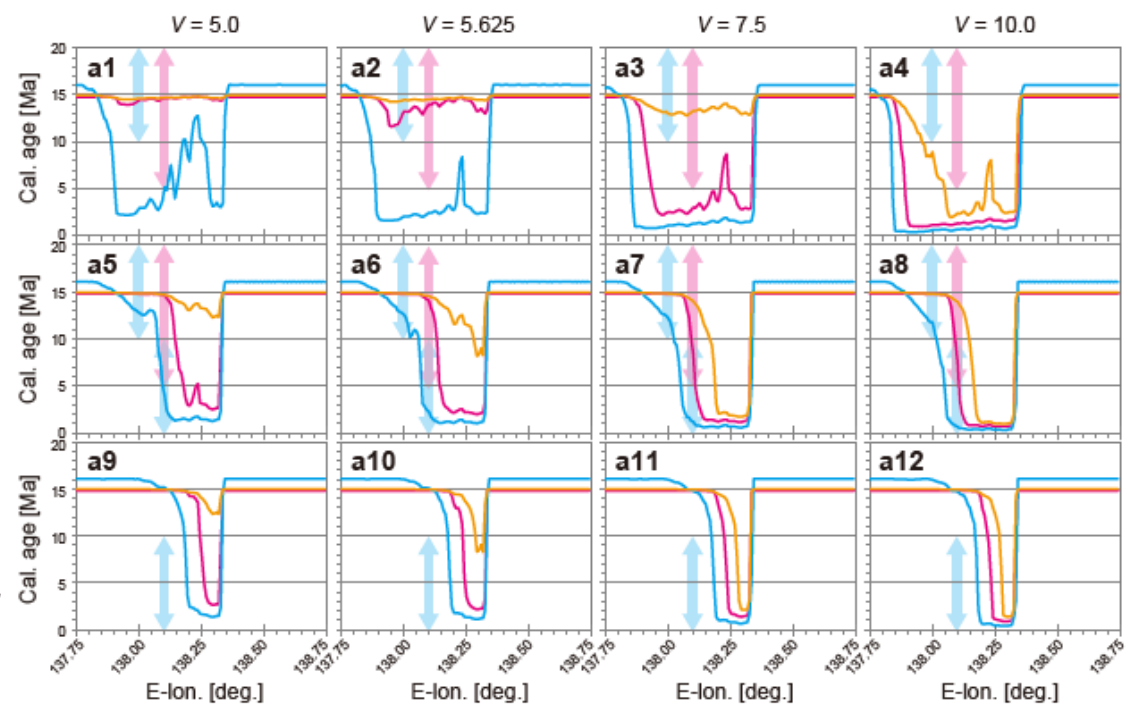

(b)

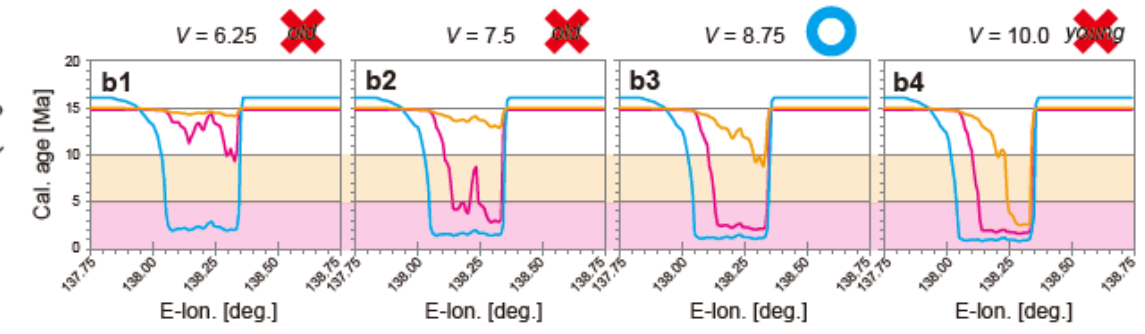

(c)
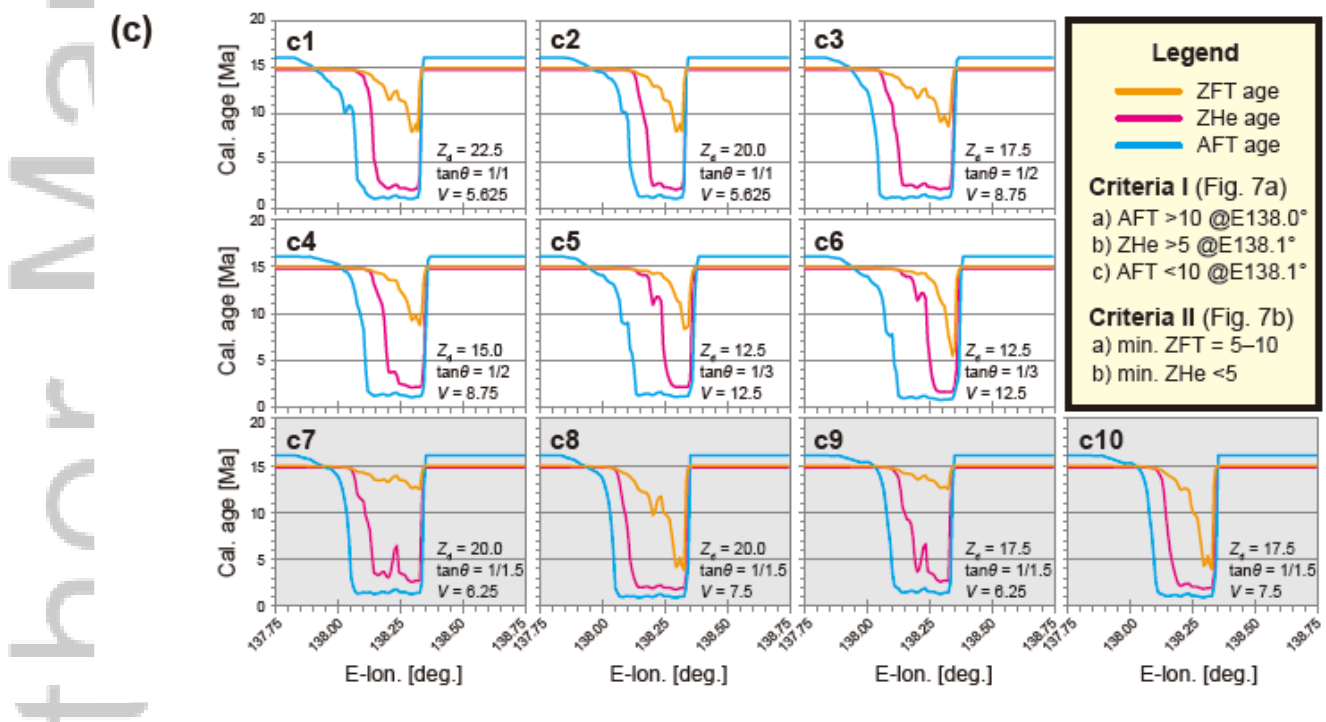

c10

Figure7. Thermo-kinematic modelingresults and criteria. The results are obtained along N-lat. $=35.75^{\circ}$, with a projection line shown in Figure 6a.(a) Criteria I on the range of the younger ages (Table 5).The typical cases in which the range is too wide then failed Criteria $\mathrm{Ia}$ or $\mathrm{Ib}$ (a1-a4), with a moderate range they passed Criteria Ia,b,c (a5-a8), and with a too narrow range they failed Criterion Ic (a9-a12).(b) Criteria II on the youngest ages (Table 6). It corresponds to the typical cases in which the youngest ages are too old, namely, ZHe age $>5$ Ma and/or ZFT age >10 Ma (b1-b2); they are moderate and passed Criteria IIa and IIb (b3) and too young, namely, the minimum ZFT age $<5 \mathrm{Ma}$ (b4); and (c) Six cases that passed both criteria I and II (c1-c6). In addition to the six cases, two more cases having slip rates between the cases $\mathrm{c} 7$ and c 8 and cases c9 and c10 (cases shown in light gray), respectively, are thought to pass the criteria I and II. 


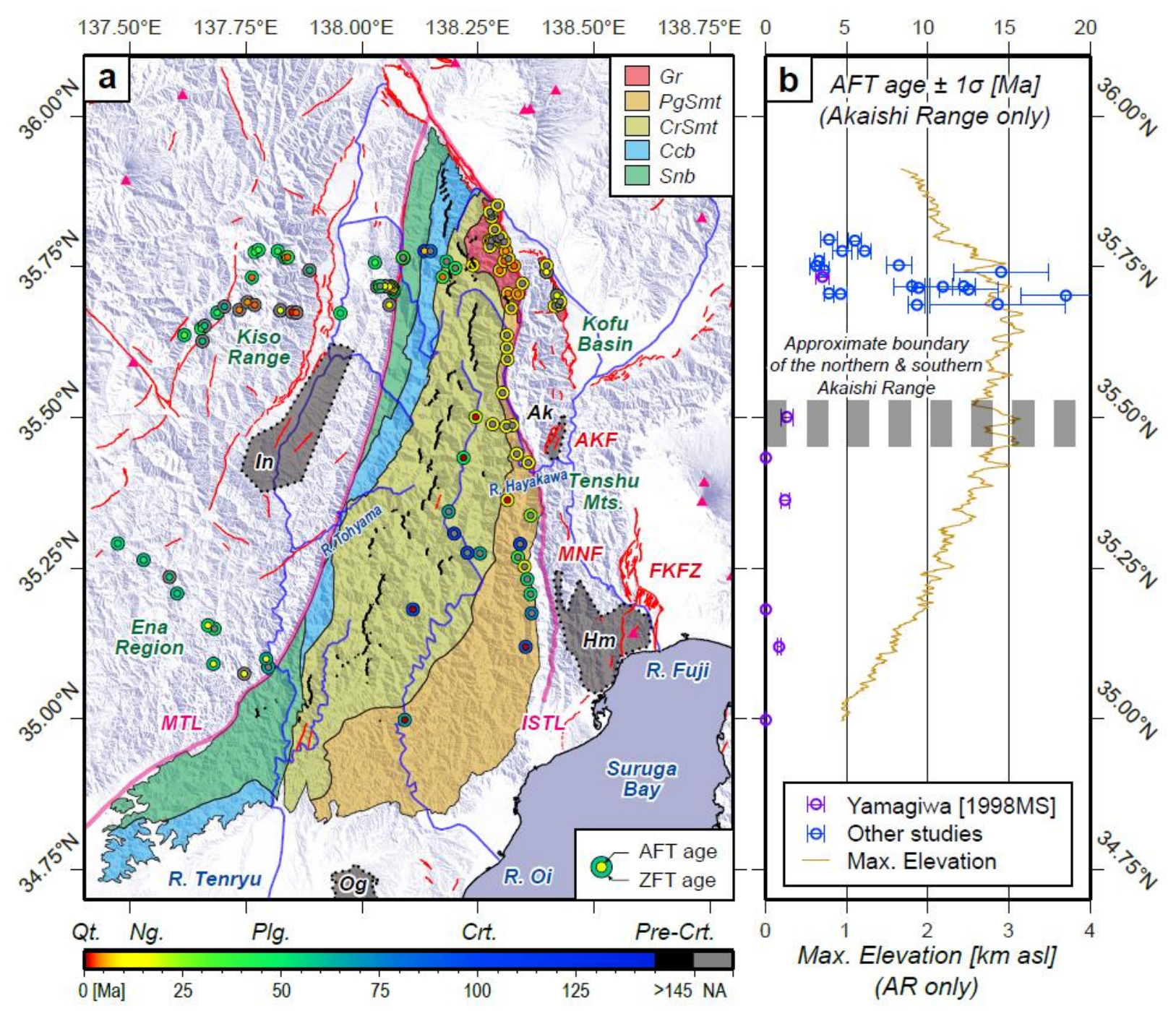

Figure8. Comparison between FT ages of the northern and southern Akaishi Range.(a) Major FT ages in and aroundtheAkaishi Range.FT ages forthe Akaishi Range are from Tagami et al. [1988a], Ito et al. [1989], Tagami and Shibata [1993], Yamagiwa et al. [1997], Yamagiwa [1998MS], and this study.FT ages for Kiso Range and Ena region are from Sueoka et al. [2012] and Tagami et al. [1988a], respectively. Black dots are points at which maximum elevation shown in Figure 8b were obtained. (b) Variation of AFT ages in the N-S direction.AFT ages shown in blue are from Yamagiwa [1998MS], whereas those shown in purple are from Tagami et al. [1988a], Tagami and Shibata [1993], and this study.AFT ages of the Kiso Range and Ena regions are not plotted.Maximum elevation indicates the highest elevation obtained along each longitude line. Ak: AkebonoConglomerate; Hm: Hamaishidake Formation and Ihara Group; In: Ina Group; Og: Ogasa Group; Gr: Kaikoma and Tsuburai Granites; PgSmt: Paleogene Shimanto Belt; CrSmt: Cretaceous Shimanto BeltCcb: Chichibu Belt including the Todai Formation; Snb: Sanbagawa Belt;ISTL: Itoigawa-Shizuoka Tectonic Line; MTL: Median Tectonic Line; FKFZ: Fujikawa Kako Fault Zone; MNF: Minobu fault; AKF: Akebono fault. 


\begin{tabular}{|c|c|c|c|c|c|c|c|c|c|c|c|c|c|}
\hline \multirow[b]{2}{*}{$\begin{array}{l}\text { Sample } \\
\text { code }\end{array}$} & \multirow[b]{2}{*}{ Rock type } & \multirow[b]{2}{*}{$\begin{array}{c}\text { Geol. } \\
\text { unit }\end{array}$} & \multirow[b]{2}{*}{ Mineral } & Grains & \multirow[b]{2}{*}{$N_{\mathrm{s}}$} & \multirow[b]{2}{*}{$\begin{array}{c}\rho_{\mathrm{s}} \\
{\left[10^{6} \mathrm{~cm}^{-2}\right]}\end{array}$} & \multirow[b]{2}{*}{$\begin{array}{c}{ }^{238} \mathrm{U} \\
{[\mathrm{ppm}]}\end{array}$} & \multirow[b]{2}{*}{$\begin{array}{c}t_{\text {pooled }} \pm 1 \sigma \\
{[\mathrm{Ma}]}\end{array}$} & \multirow[b]{2}{*}{$\begin{array}{c}\mathrm{P}\left(\mathrm{Q}_{\text {stat }}\right) \\
{[\%]}\end{array}$} & \multirow[b]{2}{*}{$\begin{array}{c}\mathrm{Cl} \\
{[\mathrm{wt} \%]}\end{array}$} & \multicolumn{3}{|c|}{ Locality (WGS84) } \\
\hline & & & & $\begin{array}{ll}\text { all-in } \quad \begin{array}{l}\text { (zero } \\
\text { age) }\end{array}\end{array}$ & & & & & & & $\begin{array}{c}\text { E-lon. } \\
{\left[{ }^{\circ}\right]}\end{array}$ & $\begin{array}{c}\text { N-lat. } \\
{\left[{ }^{\circ}\right]}\end{array}$ & $\begin{array}{c}\text { Elv. } \\
{[\mathrm{m} \text { asl }]}\end{array}$ \\
\hline$\# 10$ & $\begin{array}{l}\text { Alternating psammitic } \\
\text { and pelitic schists }\end{array}$ & Snb & zircon & 23 & 2164 & 6.0 & 248.3 & $45.5 \pm 1.4$ & 0.0 & & 138.0856 & 35.7677 & 856 \\
\hline$\# 9$ & Sandstone & $\mathrm{TdF}$ & zircon & 16 & 2707 & 7.2 & 123.2 & $109.4 \pm 2.8$ & 0.0 & & 138.1310 & 35.7788 & 975 \\
\hline \#9 & & & apatite & $81(14)$ & 258 & 0.067 & 21.7 & $6.1 \pm 0.4$ & 0.0 & 1.21 & & & \\
\hline$\# 8$ & Sandstone & $\mathrm{Ccb}$ & zircon & 22 & 1761 & 9.6 & 221.7 & $81.7 \pm 2.7$ & 0.0 & & 138.1432 & 35.7792 & 1010 \\
\hline$\# 7$ & Sandstone & Smt & zircon & 27 & 3658 & 6.7 & 229.4 & $54.9 \pm 1.6$ & 0.0 & & 138.1781 & 35.7618 & 1594 \\
\hline$\# 5$ & Granite & $\mathrm{KGr}$ & zircon & 23 & 619 & 2.7 & 519.5 & $10.0 \pm 0.5$ & 14.4 & & 138.2352 & 35.7557 & 2740 \\
\hline$\# 5$ & & & apatite & $76(22)$ & 126 & 0.032 & 7.6 & $8.2 \pm 0.8$ & 0.0 & 0.73 & & & \\
\hline Ojr1 & Granite & $\mathrm{KGr}$ & zircon & 22 & 1228 & 3.3 & 737.7 & $8.5 \pm 0.3$ & 0.0 & & 138.2704 & 35.7968 & 1278 \\
\hline Ojr1 & & & apatite & $82(17)$ & 210 & 0.043 & 15.4 & $5.5 \pm 0.4$ & 0.0 & 0.17 & & & \\
\hline Ojr2 & Granite & KGr & zircon & 24 & 711 & 2.5 & 676.8 & $7.0 \pm 0.4$ & 16.0 & & 138.2875 & 35.7986 & 1164 \\
\hline Ojr2 & & & apatite & $81(37)$ & 68 & 0.012 & 6.1 & $3.9 \pm 0.5$ & 0.0 & 0.10 & & & \\
\hline Ojr3 & Granite & $\mathrm{KGr}$ & zircon & 21 & 385 & 2.7 & 736.2 & $6.9 \pm 0.4$ & 0.2 & & 138.2936 & 35.7951 & 772 \\
\hline Ohm 1 & Granite & $\mathrm{KGr}$ & zircon & 26 & 945 & 3.2 & 819.0 & $7.5 \pm 0.3$ & 1.1 & & 138.2927 & 35.7472 & 995 \\
\hline Ohm1 & & & apatite & $82(22)$ & 176 & 0.039 & 21.1 & $3.6 \pm 0.3$ & 0.0 & 0.21 & & & \\
\hline Ohm2 & Granite & KGr & zircon & 22 & 712 & 2.8 & 738.4 & $7.1 \pm 0.3$ & 0.0 & & 138.3029 & 35.7625 & 823 \\
\hline $\mathrm{Ohm} 2$ & & & apatite & $81(16)$ & 179 & 0.030 & 18.1 & $3.3 \pm 0.3$ & 0.0 & 0.85 & & & \\
\hline Ohm3 & Granite & $\mathrm{KGr}$ & zircon & 31 & 646 & 2.3 & 776.5 & $5.6 \pm 0.2$ & 0.2 & & 138.3241 & 35.7546 & 824 \\
\hline $\mathrm{Ohm} 3$ & & & apatite & $84(49)$ & 59 & 0.015 & 9.3 & $3.1 \pm 0.4$ & 11.4 & 0.59 & & & \\
\hline Houl & Granite & $\mathrm{KGr}$ & zircon & 28 & 1037 & 3.9 & 913.2 & $8.2 \pm 0.3$ & 1.3 & & 138.3112 & 35.7091 & 2330 \\
\hline Hou1 & & & apatite & $80(27)$ & 134 & 0.036 & 17.9 & $3.9 \pm 0.3$ & 8.4 & 0.30 & & & \\
\hline Hou2 & Granite & $\mathrm{KGr}$ & zircon & 23 & 440 & 2.2 & 720.6 & $5.7 \pm 0.3$ & 0.0 & & 138.3316 & 35.7078 & 1510 \\
\hline Hou2 & & & apatite & $82(28)$ & 117 & 0.026 & 10.9 & $4.6 \pm 0.4$ & 0.0 & 0.13 & & & \\
\hline Ykt & Granite & $\mathrm{KGr}$ & zircon & 25 & 582 & 2.2 & 672.5 & $6.2 \pm 0.3$ & 11.7 & & 138.3066 & 35.7794 & 790 \\
\hline Ykt & & & apatite & $80(39)$ & 64 & 0.016 & 6.5 & $4.7 \pm 0.6$ & 98.5 & 0.80 & & & \\
\hline Amr & Granite & $\mathrm{TGr}$ & zircon & 36 & 1869 & 4.4 & 584.4 & $14.4 \pm 0.4$ & 11.4 & & 138.4208 & 35.6909 & 637 \\
\hline Amr & & & apatite & $18(10)$ & 12 & 0.012 & 1.7 & $14.3 \pm 4.2$ & 99.5 & 0.61 & & & \\
\hline Tzw & Granite & $\mathrm{TGr}$ & apatite & $33(14)$ & 25 & 0.017 & 2.3 & $14.5 \pm 2.9$ & 79.4 & 0.48 & 138.3941 & 35.7446 & 533 \\
\hline Tts & Granite & $\mathrm{TGr}$ & apatite & $39(14)$ & 43 & 0.020 & 2.1 & $18.5 \pm 2.8$ & 19.4 & 0.87 & 138.4158 & 35.7057 & 472 \\
\hline
\end{tabular}

Table 1.Summary of apatite and zircon FTdata.Grains indicate the number of mineral grains used for measuring spontaneous FT density, including zero-age grains; number in parentheses indicates number of zero-age grains. $N_{s}=$ number of spontaneous fission tracks, $\rho_{\mathrm{s}}=$ spontaneous fission-track density, ${ }^{238} \mathrm{U}=$ pooled mean concentration of uranium-238, $\mathrm{t}_{\text {pooled }}=$ pooled FT age, $\mathrm{P}\left(\mathrm{Q}_{\text {stat }}\right)=\chi^{2}$-probability of $\mathrm{Q}_{\text {stat }}[$ Hasebe et al., 2013], and $\mathrm{Cl}=$ chlorine content. The uncertainty of ${ }^{238} \mathrm{U}$ was estimated at $10 \%$ based on repeated measurements of NIST 610 and 612 standard glasses [Hasebe et al., 2004].KGr = Kaikoma granite; $\mathrm{TGr}=$ Tsuburai granite; $\mathrm{Smt}=$ Shimanto Belt; $\mathrm{Ccb}=$ Chichibu Belt; $\mathrm{TdF}=$ Todai Formation;and Snb = Sanbagawa Belt. 


\begin{tabular}{|c|c|c|c|c|c|c|c|c|c|}
\hline $\begin{array}{l}\text { Sample } \\
\text { Code }\end{array}$ & $\begin{array}{c}\text { Lab. ID } \\
\text { No. }\end{array}$ & $\begin{array}{c}\text { Corr. He } \\
\text { [ncc] }\end{array}$ & $\begin{array}{c}\text { Mass } \\
{[\mathrm{mg}]}\end{array}$ & Mean $\mathrm{F}_{T}$ & $\begin{array}{c}\mathrm{U} \\
{[\mathrm{ppm}]}\end{array}$ & $\begin{array}{c}\text { Th } \\
{[\mathrm{ppm}]}\end{array}$ & $\mathrm{Th} / \mathrm{U}$ & $\mathrm{eU}$ & $\begin{array}{c}\text { Age } \pm 1 \sigma \\
{[\mathrm{Ma}]}\end{array}$ \\
\hline$\# 5$ & 5857 & 9.695 & 0.0076 & 0.79 & 909.2 & 745.8 & 0.82 & 1084.5 & $9.7 \pm 0.6$ \\
\hline$\# 5$ & 5858 & 21.049 & 0.0205 & 0.84 & 818.0 & 413.3 & 0.51 & 915.1 & $9.2 \pm 0.6$ \\
\hline$\# 5$ & 5859 & 11.875 & 0.0145 & 0.81 & 747.2 & 411.4 & 0.55 & 843.9 & $8.0 \pm 0.5$ \\
\hline \multicolumn{9}{|c|}{ Weighted mean age $\pm 95 \%$ c.l. $[\mathrm{Ma}]:$} & $8.8 \pm 2.2$ \\
\hline$\# 9$ & 5851 & 7.893 & 0.0088 & 0.80 & 457.2 & 148.1 & 0.32 & 492.0 & $15.0 \pm 0.9$ \\
\hline \#9 & 5852 & 3.032 & 0.0059 & 0.78 & 264.9 & 150.4 & 0.57 & 300.2 & $14.0 \pm 0.9$ \\
\hline \multicolumn{9}{|c|}{ Weighted mean age $\pm 95 \%$ c.l. $[\mathrm{Ma}]:$} & $14.5 \pm 1.2$ \\
\hline$\# 10$ & 5848 & 8.164 & 0.0104 & 0.80 & 300.3 & 189.7 & 0.63 & 344.8 & $18.6 \pm 1.2$ \\
\hline$\# 10$ & 5849 & 23.076 & 0.0176 & 0.85 & 473.0 & 115.9 & 0.25 & 500.3 & $21.5 \pm 1.3$ \\
\hline$\# 10$ & 5850 & 7.487 & 0.0090 & 0.81 & 616.2 & 246.5 & 0.40 & 674.1 & $10.2 \pm 0.6$ \\
\hline \multicolumn{9}{|c|}{ Weighted mean age $\pm 95 \%$ c.l. $[\mathrm{Ma}]:$} & - \\
\hline AKS03 & 5854 & 10.295 & 0.0102 & 0.80 & 711.7 & 435.4 & 0.61 & 814.0 & $10.2 \pm 0.6$ \\
\hline AKS03 & 5855 & 7.807 & 0.0100 & 0.81 & 552.0 & 237.0 & 0.43 & 607.7 & $10.6 \pm 0.7$ \\
\hline AKS03 & 5856 & 12.237 & 0.0134 & 0.83 & 647.2 & 154.9 & 0.24 & 683.6 & $10.9 \pm 0.7$ \\
\hline \multicolumn{9}{|c|}{ Weighted mean age $\pm 95 \%$ c.l. $[\mathrm{Ma}]:$} & $10.6 \pm 0.7$ \\
\hline OHM-1 & 5866 & 11.240 & 0.0220 & 0.85 & 715.0 & 304.8 & 0.43 & 786.6 & $5.3 \pm 0.3$ \\
\hline OHM-1 & 5867 & 8.123 & 0.0153 & 0.83 & 1008.5 & 346.6 & 0.34 & 1090.0 & $4.0 \pm 0.2$ \\
\hline OHM-1 & 5868 & 7.049 & 0.0134 & 0.82 & 965.4 & 351.3 & 0.36 & 1048.0 & $4.1 \pm 0.3$ \\
\hline \multicolumn{9}{|c|}{ Weighted mean age $\pm 95 \%$ c.l. $[\mathrm{Ma}]:$} & $4.4 \pm 1.6$ \\
\hline OHM-2 & 5869 & 8.453 & 0.0176 & 0.82 & 745.3 & 421.3 & 0.57 & 844.3 & $4.7 \pm 0.3$ \\
\hline OHM-2 & 5870 & 16.546 & 0.0179 & 0.82 & 1086.6 & 417.9 & 0.38 & 1184.8 & $6.4 \pm 0.4$ \\
\hline OHM-2 & 5871 & 5.516 & 0.0156 & 0.83 & 610.7 & 312.7 & 0.51 & 684.2 & $4.3 \pm 0.3$ \\
\hline \multicolumn{9}{|c|}{ Weighted mean age $\pm 95 \%$ c.l. $[\mathrm{Ma}]:$} & $4.8 \pm 2.4$ \\
\hline OJR-1 & 5875 & 9.726 & 0.0162 & 0.82 & 632.9 & 333.6 & 0.53 & 711.3 & $6.9 \pm 0.4$ \\
\hline OJR-1 & 5876 & 8.940 & 0.0132 & 0.82 & 855.7 & 555.1 & 0.65 & 986.2 & $5.6 \pm 0.3$ \\
\hline OJR-1 & 5877 & 5.939 & 0.0094 & 0.79 & 816.1 & 521.4 & 0.64 & 938.6 & $5.5 \pm 0.3$ \\
\hline \multicolumn{9}{|c|}{ Weighted mean age $\pm 95 \%$ c.l. $[\mathrm{Ma}]:$} & $5.9 \pm 1.8$ \\
\hline OJR-2 & 5878 & 6.438 & 0.0107 & 0.81 & 960.4 & 508.4 & 0.53 & 1079.9 & $4.6 \pm 0.3$ \\
\hline OJR-2 & 5879 & 8.921 & 0.0093 & 0.80 & 1718.3 & 594.4 & 0.35 & 1858.0 & $4.2 \pm 0.3$ \\
\hline \multicolumn{9}{|c|}{ Weighted mean age $\pm 95 \%$ c.l. $[\mathrm{Ma}]:$} & $4.4 \pm 0.4$ \\
\hline OJR-3 & 5881 & 1.179 & 0.0073 & 0.78 & 387.2 & 206.8 & 0.53 & 435.8 & $3.0 \pm 0.2$ \\
\hline OJR-3 & 5882 & 1.253 & 0.0051 & 0.76 & 441.4 & 298.3 & 0.68 & 511.5 & $4.0 \pm 0.2$ \\
\hline OJR-3 & 5883 & 2.213 & 0.0054 & 0.77 & 882.0 & 474.5 & 0.54 & 993.5 & $3.4 \pm 0.2$ \\
\hline \multicolumn{9}{|c|}{ Weighted mean age $\pm 95 \%$ c.l. $[\mathrm{Ma}]:$} & $3.4 \pm 1.1$ \\
\hline
\end{tabular}

Table 2.Summary of zircon (U-Th)/He data. $\mathrm{F}_{\mathrm{T}}$ is the $\alpha$-ejection correlation obtained from Farley et al.[1996] and Hourigan et al. [2005]. "Corr. He" is ${ }^{4} \mathrm{He}$ content corrected by $\mathrm{F}_{\mathrm{T}}$.Weighted mean ages and their errors are calculated using IsoPlot [Ludwig, 2003].eU is the effective uranium concentration, weights $U$ and $T h$ for their alpha productivity, computed as $[\mathrm{U}]+0.235[\mathrm{Th}][$ Shuster et al., 2006]. Weighted mean age of \#10 is not obtained because of the wide dispersion of the grain ages.AKS03 is a sandstone sample collected from Akaishi Group of Shimanto Belt, for which ZFT age of 40.5 $\pm 1.7 \mathrm{Ma}$ and AFT age of 3.5 $\pm 0.7 \mathrm{Ma}$ $(2 \sigma)$ were reported [Yamagiwa et al., 1997; Yamagiwa, 1998MS]. 


\begin{tabular}{lcccccccccc}
\hline \multicolumn{1}{c}{ Sample } & Mineral & Grains & $N_{\mathrm{s}}$ & $\begin{array}{c}\rho_{\mathrm{s}} \\
{\left[10^{6} \mathrm{~cm}^{-2}\right]}\end{array}$ & $\begin{array}{c}{ }^{238} \mathrm{U} \\
{[\mathrm{ppm}]}\end{array}$ & $\begin{array}{c}t_{\text {pooled }} \pm 2 \sigma \\
{[\mathrm{Ma}]}\end{array}$ & $\begin{array}{c}t_{\text {ref }} \pm 2 \sigma \\
{[\mathrm{Ma}]}\end{array}$ & $\begin{array}{c}\mathrm{P}\left(\mathrm{Q}_{\text {stat }}\right) \\
{[\%]}\end{array}$ & $\begin{array}{c}\text { Referene } \\
\text { Durango }\end{array}$ \\
Fish Canyon Tuff & apatite & 15 & 186 & 0.13 & 7.9 & $32.6 \pm 4.8$ & $31.4 \pm 0.5$ & 90.9 & Green $[1985]$ & \\
Buluk Member 4 & apatite & 24 & 207 & 0.16 & 12.1 & $25.8 \pm 3.8$ & $28.8 \pm 1.6$ & 7.7 & Gleadow et al. [2015] \\
OD-3 (Kawamoto Granodiorite) & zircon & 30 & 1052 & 0.85 & 104.1 & $15.5 \pm 1.0$ & $16.2 \pm 0.6$ & 22.1 & Hurford and Watkins [1987] \\
\hline
\end{tabular}

Table 3.Summary of apatite and zircon FT data for age standards. The results of OD-3 were previously published by Iwano et al. [2013].Note that the age error reported in Iwano et al. [2013] was recalculated owing to the comparison with the data of other laboratories. $\mathrm{N}_{\mathrm{s}}=$ number of spontaneous fission tracks, $\rho_{\mathrm{s}}=$ spontaneous fission-track density, ${ }^{238} \mathrm{U}=$ pooled mean concentration of uranium- $238, \mathrm{t}_{\text {pooled }}=$ pooled $\mathrm{FT}$ age, $\mathrm{t}_{\text {ref }}=$ reference age, and $\mathrm{P}\left(\mathrm{Q}_{\text {stat }}\right)$ $=\chi^{2}$-probability of $\mathrm{Q}_{\text {stat }}[$ Hasebe et al., 2013].

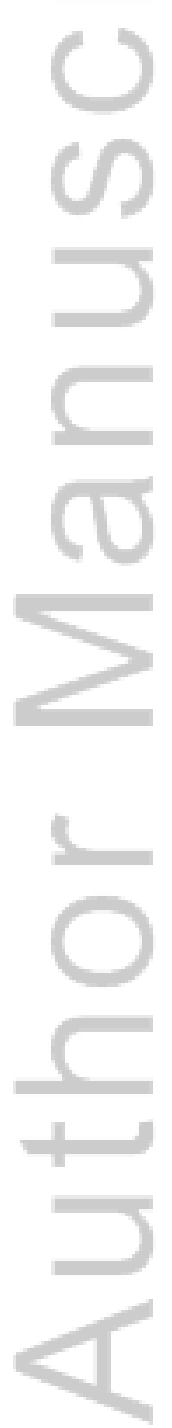

This article is protected by copyright. All rights reserved. 


\begin{tabular}{crcl}
\hline Parameters & \multicolumn{1}{c}{ Constant } & Unit & Description \\
\hline$n x, n y, n z$ & $120,90,21$ & - & Number of the grids \\
$\Delta x, \Delta y$ & $0.0083333,0.0083333$ & deg. & Grid size \\
$\rho_{\mathrm{c}}$ & 2700 & $\mathrm{~kg} / \mathrm{m}^{3}$ & Crustal density \\
$\rho_{\mathrm{m}}$ & 3200 & $\mathrm{~kg} / \mathrm{m}^{3}$ & Mantle density \\
$E$ & $1.0 \mathrm{x} 10^{11}$ & $\mathrm{~Pa}$ & Young modulus \\
$v$ & 0.25 & - & Poisson's ratio \\
$D_{\mathrm{e}}$ & 12.5 & $\mathrm{~km}$ & Elastic thickness \\
$Z_{\mathrm{max}}$ & 30 & $\mathrm{~km}$ & Model thickness \\
$\kappa$ & 25 & $\mathrm{~km}^{2} / \mathrm{Myr}$ & Thermal diffusivity \\
$T_{\mathrm{b}}$ & 750 & ${ }^{\circ} \mathrm{C}$ & Temperature at the base of the model \\
$T_{\mathrm{s}}$ & 15 & ${ }^{\circ} \mathrm{C}$ & Temperature at the sea level \\
$\Gamma$ & 6 & ${ }^{\circ} \mathrm{C} / \mathrm{km}$ & Atmospheric lapse rate \\
$H$ & 0 & ${ }^{\circ} \mathrm{C} / \mathrm{Myr}$ & Heat production \\
$t_{0}$ & 15 & $\mathrm{Ma}$ & Starting time for the simulation \\
$t_{1}$ & 3.3 & $\mathrm{Ma}$ & Starting time for the thrusting and relief growth \\
$V$ & variable & $\mathrm{mm} / \mathrm{yr}$ & Slip velocity \\
$Z_{\mathrm{d}}$ & variable & $\mathrm{km}$ & Depth of the detachment \\
$\theta$ & variable & - & Dip of the ramp \\
\hline
\end{tabular}

Table 4.Summary of thermo-kinematic modeling parameters. 


\begin{tabular}{ccccccccc}
\hline \multicolumn{2}{c}{ Dip, $\theta$} & \multicolumn{7}{c}{ Depth, $Z_{\mathrm{d}}[\mathrm{km}]$} \\
\cline { 3 - 9 }$(\tan \theta)$ & {$[$ deg. $]$} & 25.0 & 22.5 & 20.0 & 17.5 & 15.0 & 12.5 & 10.0 \\
\hline $1 / 4$ & 14.0 & $\mathrm{~W}$ & $\mathrm{~W}$ & $\mathrm{~W}$ & $\mathrm{~W}$ & $\mathrm{~W}$ & $\mathrm{~W}$ & $\mathrm{~N}$ \\
$1 / 3$ & 18.4 & $\mathrm{~W}$ & $\mathrm{~W}$ & $\mathrm{~W}$ & $\mathrm{~W}$ & $\mathrm{M}$ & $\mathrm{M}$ & $\mathrm{N}$ \\
$1 / 2$ & 26.6 & $\mathrm{~W}$ & $\mathrm{~W}$ & $\mathrm{~W}$ & $\mathrm{M}$ & $\mathrm{M}$ & $\mathrm{N}$ & $\mathrm{N}$ \\
$1 / 1.5$ & 33.7 & $\mathrm{~W}$ & $\mathrm{~W}$ & $\mathrm{M}$ & $\mathrm{M}$ & $\mathrm{N}$ & $\mathrm{N}$ & $\mathrm{N}$ \\
$1 / 1$ & 45.0 & $\mathrm{~W}$ & $\mathrm{M}$ & $\mathrm{M}$ & $\mathrm{N}$ & $\mathrm{N}$ & $\mathrm{N}$ & $\mathrm{N}$ \\
\hline
\end{tabular}

Table 5.Thermo-kinematic modeling results (pass/fail for Criteria I).Variable combinations of the ramp dip, $\theta$, and detachment depth, $Z_{\mathrm{d}}$, are tested in terms of reproducibility of the range at which the younger thermochronometric ages are observed.W: the calculated range is too wide to pass Criteria Ia or Ib; M: the calculated range is moderate and passed Criteria $\mathrm{I}$; and $\mathrm{N}=$ the calculated range is too narrow to pass Criterion Ic.See also Figure 7 regarding the detailed criteria. 


\begin{tabular}{|c|c|c|c|c|c|c|c|c|c|c|c|c|}
\hline \multirow{2}{*}{$\begin{array}{c}\text { Depth, } Z_{\mathrm{d}} \\
{[\mathrm{km}]}\end{array}$} & \multirow{2}{*}{$\begin{array}{r}\text { Dip, } \theta \\
(\tan \theta)\end{array}$} & & \multicolumn{10}{|c|}{ Slip rate, $V[\mathrm{~mm} / \mathrm{yr}]$} \\
\hline & & & 5.0 & 5.625 & 6.25 & 7.5 & 8.75 & 10.0 & 12.5 & 15.0 & 20.0 & 25.0 \\
\hline \multirow{2}{*}{12.5} & \multirow{2}{*}{$1 / 3$} & $V_{\mathrm{v}}:$ & 1.6 & 1.8 & 2.0 & 2.4 & 2.8 & 3.2 & 4.0 & 4.7 & 6.3 & 7.9 \\
\hline & & $V_{\mathrm{H}}:$ & 4.7 & 5.3 & 5.9 & 7.1 & 8.3 & 9.5 & 11.9 & 14.2 & 19.0 & 23.7 \\
\hline \multirow{2}{*}{15.0} & \multirow{2}{*}{$1 / 3$} & $V_{\mathrm{v}}:$ & 1.6 & 1.8 & 2.0 & 2.4 & 2.8 & 3.2 & 4.0 & 4.7 & 6.3 & 7.9 \\
\hline & & $V_{\mathrm{H}}:$ & 4.7 & 5.3 & 5.9 & 7.1 & 8.3 & 9.5 & 11.9 & 14.2 & 19.0 & 23.7 \\
\hline \multirow{2}{*}{15.0} & \multirow{2}{*}{$1 / 2$} & $V_{\mathrm{v}}:$ & 2.2 & 2.5 & 2.8 & 3.4 & 3.9 & 4.5 & 5.6 & 6.7 & 8.9 & 11.2 \\
\hline & & $V_{\mathrm{H}}:$ & 4.5 & 5.0 & 5.6 & 6.7 & 7.8 & 8.9 & 11.2 & 13.4 & 17.9 & 22.4 \\
\hline \multirow{2}{*}{17.5} & \multirow{2}{*}{$1 / 2$} & $V_{\mathrm{v}}:$ & 2.2 & 2.5 & 2.8 & 3.4 & 3.9 & 4.5 & 5.6 & 6.7 & 8.9 & 11.2 \\
\hline & & $V_{\mathrm{H}}:$ & 4.5 & 5.0 & 5.6 & 6.7 & 7.8 & 8.9 & 11.2 & 13.4 & 17.9 & 22.4 \\
\hline \multirow{2}{*}{17.5} & \multirow{2}{*}{$1 / 1.5$} & $V_{\mathrm{v}}:$ & 2.8 & 3.1 & 3.5 & 4.2 & 4.9 & 5.5 & 6.9 & 8.3 & 11.1 & 13.9 \\
\hline & & $V_{\mathrm{H}}:$ & 4.2 & 4.7 & 5.2 & 6.2 & 7.3 & 8.3 & 10.4 & 12.5 & 16.6 & 20.8 \\
\hline \multirow{2}{*}{20.0} & \multirow{2}{*}{$1 / 1.5$} & $V_{\mathrm{v}}:$ & 2.8 & 3.1 & 3.5 & 4.2 & 4.9 & 5.5 & 6.9 & 8.3 & 11.1 & 13.9 \\
\hline & & $V_{\mathrm{H}}:$ & 4.2 & 4.7 & 5.2 & 6.2 & 7.3 & 8.3 & 10.4 & 12.5 & 16.6 & 20.8 \\
\hline \multirow{2}{*}{20.0} & \multirow{2}{*}{$1 / 1$} & $V_{\mathrm{v}}:$ & 3.5 & 4.0 & 4.4 & 5.3 & 6.2 & 7.1 & 8.8 & 10.6 & 14.1 & 17.7 \\
\hline & & $V_{\mathrm{H}}:$ & 3.5 & 4.0 & 4.4 & 5.3 & 6.2 & 7.1 & 8.8 & 10.6 & 14.1 & 17.7 \\
\hline \multirow{2}{*}{22.5} & \multirow{2}{*}{$1 / 1$} & $V_{\mathrm{v}}:$ & 3.5 & 4.0 & 4.4 & 5.3 & 6.2 & 7.1 & 8.8 & 10.6 & 14.1 & 17.7 \\
\hline & & $V_{\mathrm{H}}:$ & 3.5 & 4.0 & 4.4 & 5.3 & 6.2 & 7.1 & 8.8 & 10.6 & 14.1 & 17.7 \\
\hline
\end{tabular}

Table 6. Thermo-kinematic modeling results (pass/fail for Criteria II).Variable rates of the fault slip, $V$, are tested for the five cases that passed Criteria I (Table 5) in terms of reproducibility of the youngest thermochronometric ages observed.Cells in light gray denote that the youngest ages calculated are too old to pass Criteria II, i.e., the minimum ZHe age $>5$ Ma or the minimum ZFT age $>10$ Ma.Cells in gray passed Criteria II, i.e., the youngest ZHe and ZFT ages are $<5 \mathrm{Ma}$ and 10-5 Ma, respectively.Cells in dark gray denote that the youngest ages calculated are too young, i.e., the youngest ZFT age $<5 \mathrm{Ma}$. See also Figure 7 regarding the criteria. $V_{\mathrm{V}}$ and $V_{\mathrm{H}}$ are vertical and horizontal slip velocities [mm/yr] that were computed by simple trigonometric calculations from the slip velocity, $V$, and the ramp $\operatorname{dip}, \theta$. 


\section{University Library}

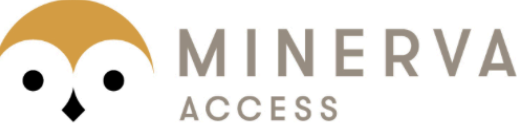

A gateway to Melbourne's research publications

Minerva Access is the Institutional Repository of The University of Melbourne

Author/s:

Sueoka, S;Ikeda, Y;Kano, K;Tsutsumi, H;Tagami, T;Kohn, BP;Hasebe, N;Tamura, A;Arai, S;Shibata, K

Title:

Uplift and denudation history of the Akaishi Range, a thrust block formed by arc-arc collision in central Japan: Insights from low-temperature thermochronometry and thermokinematic modeling

Date:

2017-08-01

Citation:

Sueoka, S., Ikeda, Y., Kano, K., Tsutsumi, H., Tagami, T., Kohn, B. P., Hasebe, N., Tamura, A., Arai, S. \& Shibata, K. (2017). Uplift and denudation history of the Akaishi Range, a thrust block formed by arc-arc collision in central Japan: Insights from low-temperature thermochronometry and thermokinematic modeling. JOURNAL OF GEOPHYSICAL RESEARCH-SOLID EARTH, 122 (8), pp.6787-6810. https://doi.org/10.1002/2017JB014320.

Persistent Link:

http://hdl.handle.net/11343/293267 